\title{
Phenolic compounds as natural feed additives in poultry and swine diets: a review
}

\author{
Shad Mahfuz, Qinghui Shang and Xiangshu Piao* (1)
}

\begin{abstract}
Due to ban on using antibiotics in feed industry, awareness of using natural feed additives have led to a great demand. The interest of plants phenolic compounds as a potential natural antioxidant source has been considered in research community due to their predictable potential role as feed additives in poultry and swine production. However, the mode of action for their functional role and dosage recommendation in animal diets are still remain indistinct. Taking into account, the present review study highlights an outline about the mode of action of phenolic compound and their experimental uses in poultry and swine focusing on the growth performance, antioxidant function, immune function, antimicrobial role and overall health status, justified with the past findings till to date. Finally, the present review study concluded that supplementation of phenolic compounds as natural feed additives may have a role on the antioxidant, immunity, antimicrobial and overall production performance in poultry and swine.
\end{abstract}

Keywords: Antioxidant role, Immune response, Phenolic compounds, Production performance, Poultry, Swine

\section{Background}

At present, the consumer's demand for safe animal food is increasing which created a challenge for animal scientists and thus the interest for using natural feed additives has been articulated [1]. Phenolics are products of plant secondary metabolism. Phenolic compounds can be defined as any compound having a benzene ring with one (phenol) or more (polyphenol) hydroxyl group as esters, methylesters etc $[1,2]$. A basic feature of phenolics are their significant antioxidant activities. In addition, some phenolics may have additional beneficial properties such as immunity, anti-inflammatory, gut health, and antimicrobial activity. Phenolic compounds have involved a great deal of research attention in nutrition and medicine of human during the last few decades. Phenolic compounds have highly antioxidant capacity

\footnotetext{
* Correspondence: piaoxsh@cau.edu.cn

State Key Laboratory of Animal Nutrition, College of Animal Science and Technology, China Agricultural University, Beijing 100193, China
}

that can play a vital role on health benefits [3]. However, the animal scientists are still recognizing phenolics as effective feed additives. With the exception of some members of the phenolics family (tannins, saponons, toxic alkaloids) the most of the plant extract did not show anti-nutritive in animal diets [4]. For example, high concentration of condensed tannins from certain plant extract in animal feed can precipitate protein digestion showed lower performance with nutrient retention in monogastric animals $[5,6]$; whereas higher body weight with improve health status in chickens offered hydrolysable tannins was recorded [7]. This is because hydrolysable tannic acid extracted from wood was enrich with polyphenolic compounds [8, 9]. Dietary inclusion of polyphenols could enhance production performance and oxidative stability of food originated from farm animals [10]. Phenolic compounds as natural metabolites have been reported to counter oxidative stress, whereas such stress are correlated with severe metabolic disorders by

(c) The Author(s). 2021 Open Access This article is licensed under a Creative Commons Attribution 4.0 International License, which permits use, sharing, adaptation, distribution and reproduction in any medium or format, as long as you give appropriate credit to the original author(s) and the source, provide a link to the Creative Commons licence, and indicate if changes were made. The images or other third party material in this article are included in the article's Creative Commons licence, unless indicated otherwise in a credit line to the material. If material is not included in the article's Creative Commons licence and your intended use is not permitted by statutory regulation or exceeds the permitted use, you will need to obtain permission directly from the copyright holder. To view a copy of this licence, visit http://creativecommons.org/licenses/by/4.0/ The Creative Commons Public Domain Dedication waiver (http://creativecommons.org/publicdomain/zero/1.0/) applies to the data made available in this article, unless otherwise stated in a credit line to the data. 
having damage to cellular and extracellular macromolecules $[11,12]$. Oxidative stress has very adverse effects on farm animal production. For example, it falls body weight by modifying optimum metabolism and reduces quality of meat by higher accumulating corticosterone in plasma that was accountable with paler color of breast meal in broiler chickens [13]. Furthermore, it could induce biological damage for DNA, protein, lipid, associated with various health effects that negatively alter production capacity in farm animals [14].

On the other hand, for more than seven decades, antibiotics have been applied at low levels for therapy and to promote growth performance in pigs and poultry [15]. Thus the antibiotics are commonly known as growth promoters for poultry and swine. It is true that antibiotics growth promoter could improve performance and could decrease mortality in pigs and poultry. But due to continue and excess uses of antibiotics in food for animal production has developed bacterial resistance to antibiotic growth promoters (AGPs) and created public health threats $[15,16]$. In Europe, AGPs in animal feed have been banned since 2006, and currently most of developed countries have prohibited on using antibiotics in feed $[15,17]$. Focusing on the beneficial roles of phenolics, it can be used as an effective natural feed additive in animals. Besides, agricultural by-products represent an excellent source of phenolic and antioxidant compounds that can be used as functional ingredients in livestock feeding [18].

Therefore, the goal of this review study was to highlight the uses and feasibility of phenolic compounds as potential natural feed additives in poultry and swine diets.

\section{Classification of phenolic compounds}

Phenolic compounds can be a simple phenolic molecule or highly polymerized compounds. Those are found naturally as chain of mono and polysaccharides, with one or more phenolic groups and may connect to esters and methyl esters [12]. Wide-ranging phenolic compounds are found in nature for their diverse structure. Currently, about 8000 phenolic compounds structures have to be identified [12]. Common known phenolics includes phenolic acid, flavonoids, tannins, avenanthramides, alkylresorcinols, oligomeric proanthocyanidins and lignans etc $[1,2]$. The source of phenolic compounds is mostly in plant tissues like grains, vegetables, fruits, trees and their extract $[2,19]$. However, in human food, the common phenolic compounds are phenolic acids, flavonoids, and tannins [12]. Classification and structure of some common of phenolics were shown in Table 1 and Table 2 respectively.

\section{Application of phenolic compounds in poultry and swine diets}

The perception of applying natural polyphenols in poultry and swine diets has been tested since 1989 [27] and later on it was considered for further research during the last two decades due to their potential biological roles $[6,28]$. The biological role of phenolic compounds with their mode of action in farm animals were described in details below.

\section{Phenolic compounds as growth promoters}

The dietary uses of different plants and their extract as phenolic sources has examined as potential tools on improving growth performance, and decline mortality in farm animals [1]. The mechanism of phenolic compounds that may act as growth promoters for the farm animals, by enhancing digestive enzyme secretions (endogenous digestive enzymes, saliva, bile and mucus) and by decreasing the pathogenic bacterial number in GIT or by modulating gut morphology due to their antioxidant and anti-inflammatory functions [29, 30]. In addition, phenolic compounds originated from aromatic plants may improve the flavor and palatability of the feed and thus increase the feed intake and growth performance [1]. Scientific studies also noted that the higher growth rate and improve FCR in poultry fed with phenolic compounds were due to altering intestinal surface area as well as digestive enzyme activities which resulted in better nutrient absorption [31, 32]. Conversely, lower feed intake was also recorded at higher inclusion level of phenolic compounds at approximate above $1500 \mathrm{mg} / \mathrm{kg}$ diets in swine due to strong odor [33]. Thus it was recommended to avoid higher dosage

Table 1 Classification of phenolic compounds

\begin{tabular}{|c|c|c|c|}
\hline Items & Example & Source & Ref. \\
\hline $\begin{array}{l}\text { Soluble } \\
\text { component }\end{array}$ & $\begin{array}{l}\text { Phenolic acid: (gallic, protocatechuic, rosmarinic, gentisic, salicylic,vanillic, } \\
\text { syringic, ferulic, caffeic, sinapic, cinnamic); flavonoid (flavones, flavonols, } \\
\text { catechin, quercetin); quinines, phenolic diterpenes (carnasol, carnosic acid) } \\
\text { and hydrolysable tannins }\end{array}$ & $\begin{array}{l}\text { Millet, oat, sorghum, barley, } \\
\text { wheat, rye, vegetable, fruits spices, } \\
\text { herbs and their byproducts }\end{array}$ & [20-22] \\
\hline $\begin{array}{l}\text { Non-soluble } \\
\text { component }\end{array}$ & Condensed tannins and lignins & $\begin{array}{l}\text { Chestnut wood, pinewood and different } \\
\text { trees and their byproducts }\end{array}$ & {$[9,23,24]$} \\
\hline $\begin{array}{l}\text { Others (aromatic } \\
\text { compound) }\end{array}$ & Alcohols (borneal); aldehyde (cinnamaldehyde); ketons (carvones) & $\begin{array}{l}\text { Aromatic plants and herbs and their } \\
\text { byproducts, cinnamon, etc }\end{array}$ & {$[25,26]$} \\
\hline
\end{tabular}


Table 2 Structure of phenolic compounds in plants

\begin{tabular}{ll}
\hline Class & Structure \\
\hline Simple phenolics, benzoquinones & $\mathrm{C} 6$ \\
Hydroxybenzoic acids & $\mathrm{C} 6-\mathrm{C} 1$ \\
Acetophenones, phenylacetic acids & $\mathrm{C} 6-\mathrm{C} 2$ \\
Hydroxycinnamic acids, phenylpropanoids & $\mathrm{C} 6-\mathrm{C} 3$ \\
Xanthones & $\mathrm{C} 6-\mathrm{C} 1-\mathrm{C6} 6$ \\
Stilbenes, anthraquinones & $\mathrm{C6}-\mathrm{C} 2-\mathrm{C6}$ \\
Flavonoids, isoflavonoids & $\mathrm{C} 6-\mathrm{C} 3-\mathrm{C6}$ \\
Lignans, neolignans & $(\mathrm{C6} 6-\mathrm{C} 3)_{2}$ \\
Lignins & $(\mathrm{C} 6-\mathrm{C} 3)_{n}$ \\
Condensed tannins (proanthocyanidins or flavolans) & $(\mathrm{C6} 6-\mathrm{C} 3-\mathrm{C} 6)_{n}$
\end{tabular}

Source: Ref. [12]

in porcine diets due to their strong sensitive palate [34]. Phenolic compounds derived from aromatic plants and extracts had a role on keeping the optimum balance between the useful bacteria and pathogenic bacteria in GIT which help to maintaining sound gut health and ultimate growth enhancer [35-37]. The growth promoting role of phenolic compounds can also be justified by improving feed status while adding phenolic in diets leads better fermentation of diets resulting in more nutrient absorption and direct or indirect anabolic roles on host tissues [30, 38]. However, the mechanism of action of phenolic compounds may vary on its structure, inclusion levels, pharmacokinetics, experimental animal species, stage of animals and duration of trail [30]. Abdel-Wareth et al. [39] has conducted an experiment to evaluate the role of thyme and oregano essential oil (thymol and carvacrol) on broilers and observed higher average daily gain (ADG) with improved feed conversion ratio (FCR) in supplemented diets than control. The authors finally concluded that, thyme and oregano at the level of 15 or $20 \mathrm{~g} / \mathrm{kg}$ diet can be applied as feed additives to improve growth performance in broilers. In addition, supplementation of oregano powder as phenolic compound at $150 \mathrm{mg} / \mathrm{kg}$ could increase about $8.4 \%$ higher ADG, along with $7.9 \%$ higher feed intake (FI) at the whole experimental period of broilers [40]. Furthermore, broilers supplemented with a mixture of thymol and carvacrol could enhance ADG with FCR via improving digestive enzyme activities [41]. Thyme oil at $1.0 \mathrm{~g} /$ $\mathrm{kg}$ diet was every effective as potential growth promoter in broilers reared under hot climate [42]. Compared with control diets, lower FCR in broilers fed with grape pomace concentrate at $60 \mathrm{~g} / \mathrm{kg}$ was noted [32]. Similarly, higher body weight gain, final body weight with lower FCR were recorded in broilers offered with grape seed as a source of phenolic compounds [43]. Broilers fed with essential oil (thyme) at $0.3 \mathrm{~g} / \mathrm{kg}$ was very useful to improve gut morphology and to increase digestive enzyme [44]. In addition, dietary inclusion of $0.3 \mathrm{~g} / \mathrm{kg}$ cinnamon oil could enhance $5.1 \%$ daily weight gain and could improve nutrient digestibility while decrease nitrogen content in excreta of commercial broilers [45]. Dietary supplementation of essential oils derived from thyme (Thymus vulgaris), peppermint (Mentha piperita) and eucalyptus (Eucalyptus globules) at $150 \mathrm{ppm}$ into drinking water could progress body weight, immune response, ileal structure and microflora in broilers [46]. Oral application of carvacol essential oil in broilers at 300 or 400 $\mu \mathrm{L}$ had a good role on body growth and intestinal barrier function via increasing the gene expression of occludin, claudin-1, claudin-5, ZO-1 and ZO-2 in mucosa [47]. In contrast, broilers fed with tannic acid as phenolic compound derived from chestnut wood at $2 \mathrm{~g} / \mathrm{kg}$ had no effects on growth performance but could reduce the rate of footpad dermatitis lesions [48]. The antigrowth of broilers may due to the anti-nutritional effects of tannins that could attribute the protein binding capacity as well as could reduce the nutrient digestibility in birds at higher dosages [48]. Laying hen fed with oregano essential oil at $100 \mathrm{mg} / \mathrm{kg}$ could increase $5 \%$ egg production percent, and could improve egg weight, FCR, amylase and trypsin enzyme activities [49]. Higher egg production with lower FCR in laying hens fed with thyme and rosemary dry leaf powder as phenolic compounds at $0.9 \%$ level was also reported [50]. In contrast, dietary inclusion of thyme essential oil at $300 \mathrm{mg} / \mathrm{kg}$ could not improve egg production and egg quality in laying hen which may due to different inclusion level and form of supplement in diets of birds [51]. In Pekin ducks, a study noted that dietary inclusion of grape seed extract (anthocyanidins, catechins) as phenolic compounds at $0.2 \%$ diets could increase about $3.1 \%$ final body weight, and could improve FCR, antioxidant status, immunity, meat quality, and beneficial microflora of gut [52]. In another recent study, dietary supplementation with combination of essential oil (cinnamaldehyde 15\%, and thymol 5\%) with organic acids could enhance about $13.5 \%$ average daily weigh gain and about $5.6 \%$ higher final body weigh in weaned piglets [53]. However, supplementation of chestnut tannin (750 mg tannic acid/kg DM) as phenolic compounds at $0.3 \%$ level in Italian heavy pigs could not improve any performance parameters, slaughter traits and energy or protein utilization [54].

\section{Phenolic compounds on meat quality}

Phenolic compounds have direct or indirect role on meat quality. In a study by Luna et al. [55] used $150 \mathrm{mg} /$ $\mathrm{kg}$ of thymol, or $150 \mathrm{mg} / \mathrm{kg}$ of carvacrol as natural polyphenol on lipid oxidation in broiler's meat and observed lower values of TBARS in thigh muscle after 5 to $10 \mathrm{~d}$ of storage than the control group. The author concluded that thymol or carvacrol as natural antioxidant could be 
useful to improve meat quality of broilers. In contrast, supplementation of grape seed had no effects on physical and chemical composition of meat in broilers [43]. It has been reported that dietary supplementation of hesperidin could improve the oxidative stability via lowering the MDA levels in yolk of fresh eggs and eggs of 30 to $90 \mathrm{~d}$ of storages [56]. In a consequence study, supplementation of broiler diets with hesperidin and naringin as flavonoid compounds derived from citrus plants could decrease MDA levels in breast muscle after $6 \mathrm{~d}$ of storage but the supplementation diets had no effects on meat color, $\mathrm{pH}$, and cooling loss percent in breast muscle of broilers [57]. In contrast, a significant higher value in meat color (lightness value) with higher $\mathrm{pH}$, and water holding capacity in broilers fed with hesperidin and genistein at $20 \mathrm{mg} / \mathrm{kg}$ diets was reported [58]. Similarly, a lower MDA value in breast muscle after $15 \mathrm{~d}$ of storage was also recorded in broilers fed with hesperidin and genistein at $20 \mathrm{mg} / \mathrm{kg}$ diets [58]. The values for redness, saturation index, shear force, odor, taste, and overall sensory acceptability of breast meat were higher in broilers fed with oregano essential oils (Poliomintha longiflora) at $400 \mathrm{mg} / \mathrm{L}$ drinking water [59]. The author finally concluded that oregano essential oils can be used as natural additives to improve meat quality of broilers. Gallic acid and linoleic acid at 1\% level also could improve antioxidant capacity and the content of phenolic was about $4 \%$ higher in breast muscle of experimental broilers [60]. Thyme essential oil has been proved to inactivate the Salmonella enteritidis on ready to eat turkey meat products during preservation [61]. Microencapsulated complex of organic acids and essential oils (thymol $1.7 \%$ and vanillin $1.0 \%$ ) at $0.2 \%$ level could improve red color value of meat and decreased drip loss about 30\% percent in weaning to finishing pigs [62]. In addition, oregano (Origanum vulgare) essential oil at $0.2 \%$ level could improve the oxidative stability of meat in pigs [63].

\section{Phenolic compounds on antioxidant function}

Phenols have naturally antioxidants properties, and can protect biomolecules (proteins, nucleic acids, polyunsaturated lipids, and sugars) from oxidative damage via free radical-mediated reactions [64]. The basic mode of action for anti-oxidative power of phenolic compounds are related with reducing properties as hydrogen or electron donation that made those compounds as freeradical scavengers (antioxidants). Further, those compounds have metal chelating activities, especially for iron and copper, and can suppress the formation of metalcatalyzed free radicals [12]. Those anti-oxidative role depends on hydroxyl group number, position and the relationship with the carboxyl functional groups [12, 65]. Moreover, the antioxidant properties of phenolic compounds are associated with the structural function relationship [66], glycosylation, and the atoms in the rings [67]. The another pathway for the anti-oxidative role of phenolic compounds may behinds on decreasing the DPPH with an effective concentration more than $50 \%$ and to reduce lipid oxidative reaction with an inhibitory concentration more than $50 \%\left(\mathrm{IC}_{50}\right)$ [15]. In brief, the donating capacity of hydrogens or electrons and to delocalizing the unpaired electrons within phenolic ring are the main mechanism of protecting biological molecules against oxidation [37, 15]. Reactive oxygen radicals can attack the surface of the intestinal mucosa, and prevent the absorption of nutrients whereas antioxidant plays a vital role on neutralizing reactive oxygen radicals and keeps better environment in intestinal surface [30].

Broiler diets supplemented with a mixture of thymol and carvacrol could increase SOD, GSH-Px, and reduced MDA levels in thigh muscle, serum and liver sample [41]. The oxidative susceptibility of liver and breast muscle was improved in broilers fed with thymol (200 $\mathrm{mg} / \mathrm{kg}) ;$ tannic acid and gallic acid (5 g/ $\mathrm{kg}$ ) diets [10]. In a study, broilers offered grape seed as a source of total phenol $55.5 \mathrm{~g} / \mathrm{kg}$, total flavonoids $19.5 \mathrm{~g} / \mathrm{kg}$, and total tannin $9.4 \mathrm{~g} / \mathrm{kg}$ diets [43]. The study observed higher SOD, CAT, GSH-Px, GST, GSH value and lower TBARS value in plasma of broilers offered grape seed as polyphenolic compounds [43]. The author justified that the polyphenol present in grape seed has been absorbed sufficiently to enhance the antioxidant function in experimental broilers. Similarly, dietary vitamin E could be replaced with grape polyphenol at $75 \mathrm{mg} / \mathrm{kg}$ on similar antioxidant status and immune response in broilers [68]. The polyphenolic compounds exhibit in tea have been widely applied as antioxidants in animal production as well as to prevent diseases [69]. In a broilers trail the basal diets were contaminated with ochratoxin as stress factor whereas phenolic product was applied as dietary supplement and observed the higher antioxidant status in blood, and higher concentrations of non-enzymatic antioxidants in the liver and breast muscles [70]. Boilers fed with essential oil (carvacrol, cinnamaldehyde and capsicum oleoresin) at $100 \mathrm{mg} / \mathrm{kg}$ could improve the hepatic antioxidant including carotene, coenzyme and total vitamin E [71]. In addition, $150 \mathrm{mg} / \mathrm{kg}$ of oregano powder as source of phenolic compounds was used in broiler diets and found higher T-AOC with lower MDA value in serum of experimental broilers [40]. Moreover, essential oil derived from herb rosemary at $20 \mathrm{~mL} / 100$ $\mathrm{kg}$ could improve antioxidant status via increasing activity of glutathione peroxidase in heat-stressed laying hens [72]. Lower serum MDA level in laying hens fed with thyme and rosemary dry leaf powder as source of phenolic compounds at $0.9 \%$ level was also reported [50]. 
Table 3 Application of phenolic compounds with major physiological responses in poultry

\begin{tabular}{|c|c|c|c|}
\hline Phenolic compounds & Study design & Main findings & Reference \\
\hline \multicolumn{4}{|l|}{ Broilers } \\
\hline Polyphenol & $\begin{array}{l}\text { Type: Ross } 308-\text { male } \\
\text { dose: } 0,20,40,60 \mathrm{~g} / \mathrm{kg} \\
\text { source: grape pomace (Vitis vinifera) } \\
\text { form: powder } \\
\text { duration: } 0-24 \text { days }\end{array}$ & $\begin{array}{l}\text { - no effects on FI, ADG, and FCR } \\
\text { - higher thigh and drumstick weight } \\
\text { - lower abdominal fat weight } \\
\text { - lower TG, TC, LDL, AST, MDA in plasma } \\
\text { - higher SOD, GSH-Px in plasma } \\
\text { - higher antibody response in plasma }\end{array}$ & [129] \\
\hline Hydrolysable tannic acid & $\begin{array}{l}\text { Type: Arbor Acre male } \\
\text { form: powder } \\
\text { dose: } 1000 \mathrm{mg} / \mathrm{kg} \\
\text { source: commercial (chestnut wood } \\
\text { extract- } 75 \% \text { tannin) } \\
\text { duration: } 0-42 \text { days }\end{array}$ & $\begin{array}{l}\text { - higher ADG, final body weight and improve FCR } \\
\bullet \text { higher CP retention } \\
\text {-pH at } 24 \mathrm{~h} \text { was higher in breast muscle } \\
\text { - higher T-AOC, GSH-Px, SOD in serum, breast and thigh } \\
\text { muscle } \\
\text { - lower serum TC, LDL-C and urea N }\end{array}$ & {$[22]$} \\
\hline Essential oil & $\begin{array}{l}\text { Type: Ross } 308 \\
\text { dose: } 0.4 \mathrm{~mL} / \mathrm{L} \\
\text { source: dry herb (lavender flowers) } \\
\text { form: liquid } \\
\text { duration: } 0-42 \text { days }\end{array}$ & $\begin{array}{l}\text { - higher ADG and final body weight } \\
\text {-improved FCR } \\
\text { •no effects on TC, TG, glucose, and uric acid concentration } \\
\text { in serum } \\
\text { - lower Escherichia coli and coliform in ileum } \\
\text { - higher probiotic bacteria in ileum }\end{array}$ & [130] \\
\hline Polyphenol (resveratrol) & $\begin{array}{l}\text { Type: Yellow feather broilers } \\
\text { dose: } 200,350 \text { and } 500 \mathrm{mg} / \mathrm{kg} \\
\text { source: dry herb (Polygonum } \\
\text { cuspidatum) } \\
\text { form: powder } \\
\text { duration: } 28-42 \text { days }\end{array}$ & $\begin{array}{l}\text { - higher ADG } \\
\text { - higher T-SOD, CAT, GSH in serum } \\
\text { - lower corticosterone, adrenocorticotropic hormone } \\
\text { - lower TC, TG, uric acid, AST, ALT and MDA in serum }\end{array}$ & [131] \\
\hline Polyphenols (resveratrol) & $\begin{array}{l}\text { Type: Arbor Acres male broilers } \\
\text { dose: } 300 \text { and } 600 \mathrm{mg} / \mathrm{kg} \\
\text { source: commercial } \\
\text { form: powder } \\
\text { duration: } 0-42 \text { days }\end{array}$ & $\begin{array}{l}\text { - higher body weight gain } \\
\text {-improve FCR } \\
\text { - lower ALT, and AST in serum } \\
\text { - higher IgG, IgM, SOD in serum } \\
\text { - lower E. coli in cecum } \\
\text { - higher ratio of villus height to crypt depth of duodenum }\end{array}$ & [132] \\
\hline Essential oil (cinnamaldehyde) & $\begin{array}{l}\text { Type: Vencobb- } 400 \text { broilers } \\
\text { dose: } 0.3 \mathrm{~g} / \mathrm{kg} \\
\text { source: cinnamon bark oil } \\
\text { form: extract } \\
\text { duration: } 0-42 \text { days }\end{array}$ & $\begin{array}{l}\text { - higher villi height of duodenum, jejunum and ileum } \\
\text { - lower number of Escherichia coli in pre-caecal contents } \\
\text { - higher antibody titers against NDV } \\
\text { - lower TC in serum } \\
\text { - higher SOD in serum } \\
\text { - no effects on TP, glucose and TG in serum }\end{array}$ & [133] \\
\hline Polyphenols & $\begin{array}{l}\text { Type: Cobb male broilers } \\
\text { dose: } 5,7.5 \text { and } 10 \mathrm{~g} / \mathrm{kg} \\
\text { source: grape pomace (Vitis vinifera) } \\
\text { form: powder } \\
\text { duration: } 3-28 \text { days }\end{array}$ & $\begin{array}{l}\bullet \text { no effects on FI, ADG, and FCR } \\
\bullet \text { no effects on DM, CP, EE, and GE retention } \\
\bullet \text { no effects on inner organs weight } \\
\bullet \text { decreased TC in serum } \\
\bullet \text { higher IgG in serum } \\
\text { - decreased thiobarbituric acid reactive substances values } \\
\text { of breast meat } \\
\bullet \text { lower redness value of meat during storage }\end{array}$ & [134] \\
\hline Polyphenols (resveratrol) & $\begin{array}{l}\text { Type: Cobb male broilers } \\
\text { dose: } 0 \text { and } 400 \mathrm{mg} / \mathrm{kg} \\
\text { source: commercial } \\
\text { form: powder } \\
\text { duration: } 0-21 \text { days }\end{array}$ & $\begin{array}{l}\text { - higher T-AOC, CAT and lower MDA in breast muscle } \\
\text { - lower lightness value, and drip loss of meat } \\
\text { - higher redness value and pH-24h of meat }\end{array}$ & {$[135]$} \\
\hline Condensed tannins & $\begin{array}{l}\text { Type: Ross } 308 \\
\text { dose: } 125,250,500,1000 \\
\text { and } 2000 \mathrm{ppm} \\
\text { source: grape seed extract (total } \\
\text { polyphenol > 40\%) } \\
\text { form: powder } \\
\text { duration: } 0-42 \text { days }\end{array}$ & $\begin{array}{l}\text {-no effects on growth performance and mortality } \\
\text { - lower TC and LDL-C in serum } \\
\text { - higher antibody titer against NDV } \\
\text { - decrease MDA content in muscle tissue }\end{array}$ & {$[136]$} \\
\hline Polyphenols (proanthocyanidins) & $\begin{array}{l}\text { Type: Cobb-500 } \\
\text { dose: } 7.5,15 \text { and } 30 \mathrm{mg} / \mathrm{kg} \\
\text { source: commercial (grape } \\
\text { proanthocyanidins) } \\
\text { form: powder } \\
\text { duration: } 0-42 \text { days }\end{array}$ & $\begin{array}{l}\text { - no effects on FI, ADG, and FCR } \\
\text {-improved jejunum morphology } \\
\text { - higher T-SOD, ALT, ALP, and CRE concentration in serum } \\
\text { - lower MDA value in serum }\end{array}$ & {$[137]$} \\
\hline
\end{tabular}


Table 3 Application of phenolic compounds with major physiological responses in poultry (Continued)

\begin{tabular}{|c|c|c|c|}
\hline Phenolic compounds & Study design & Main findings & Reference \\
\hline $\begin{array}{l}\text { Polyphenols (flavonoids, } \\
\text { catechins, and epicatechins) }\end{array}$ & $\begin{array}{l}\text { Type: Hubbard broilers } \\
\text { dose: } 25,50 \text { and } 75 \text { ppm in replace of } \\
\text { vitamin } E \\
\text { form: powder } \\
\text { source: grape seed extract } \\
\text { duration: } 0-35 \text { days }\end{array}$ & $\begin{array}{l}\text {-higher total phenolic contents in breast and leg muscles } \\
\text { - higher NDV and IBDV antibody titers } \\
\text { •lower thiobarbituric acid reactive substances in breast and } \\
\text { leg muscles }\end{array}$ & {$[68]$} \\
\hline Polyphenols & $\begin{array}{l}\text { Type: Cobb male broilers } \\
\text { dose: } 0,5 \% \text { and } 10 \% \\
\text { source: commercial (grape pomace) } \\
\text { form: powder } \\
\text { duration: } 0-21 \text { days }\end{array}$ & $\begin{array}{l}\text { - no effects ADG, FI and FCR } \\
\text { - higher oxidative stability and PUFA content in thigh } \\
\text { muscle } \\
\text { - lower SFA content in thigh muscle }\end{array}$ & [138] \\
\hline Thyme oil & $\begin{array}{l}\text { Type: Ross } 308 \text { broilers } \\
\text { dose: } 0.5 \mathrm{~g} / \mathrm{kg} \\
\text { source: commercial (T. vulgaris) } \\
\text { form: powder } \\
\text { duration: } 0-35 \text { days }\end{array}$ & $\begin{array}{l}\text { - lower MDA in duodenal mucosa and kidney } \\
\text { - higher IgA in duodenal mucosa } \\
\text { - improve intestinal barrier integrity }\end{array}$ & [139] \\
\hline $\begin{array}{l}\text { Flavonoids (genistein and } \\
\text { hesperidin) }\end{array}$ & $\begin{array}{l}\text { Type: Arbor Acre broilers } \\
\text { dose: } 5 \mathrm{mg} / \mathrm{kg} \text { and } 20 \mathrm{mg} / \mathrm{kg} \text { and } \\
\text { mixture }(1: 4) \\
\text { source: commercial } \\
\text { form: powder } \\
\text { duration: } 1-42 \text { days }\end{array}$ & $\begin{array}{l}\text { - higher T-AOC, SOD in serum } \\
\text { - lower MDA content in serum } \\
\text { - lower TC, LDL-C, TG in serum and breast muscle } \\
\text { - improved PUFA, and ration of n-6/n-3 fatty acid }\end{array}$ & [103] \\
\hline Essential oil & $\begin{array}{l}\text { Type: Arbor Acres } \\
\text { dose: } 120 \text { ppm } \\
\text { source: oregano, anis and citrus peel } \\
\text { tree } \\
\text { form: extract } \\
\text { duration: } 0-42 \text { days }\end{array}$ & $\begin{array}{l}\text { - lower serum cholesterol } \\
\text { - lower ammonia concentration in ileum } \\
\text { - higher total polyphenolic compounds and total } \\
\text { flavonoids in serum }\end{array}$ & [140] \\
\hline $\begin{array}{l}\text { Essential oil (thymol and } \\
\text { cinnamaldehyd) }\end{array}$ & $\begin{array}{l}\text { Type: Ross broilers } \\
\text { dose: } 0.1 \mathrm{~g} / \mathrm{kg}(15 \mathrm{~g} / \mathrm{t} \text { thymol and } 5 \\
\text { g/t cinnamaldehyde) } \\
\text { source: commercial blend oil } \\
\text { form: powder } \\
\text { duration: } 0-42 \text { days }\end{array}$ & $\begin{array}{l}\text { - higher ADG } \\
\text { - higher number of Lactobacillus and Escherichia coli in } \\
\text { cecum } \\
\text { - higher proportion of caecal butyrate } \\
\text { - decreased proportion of caecal caecal acetic acid and } \\
\text { propionic acid }\end{array}$ & [141] \\
\hline Tannic acid & $\begin{array}{l}\text { Type: Ross } 308 \\
\text { dose: } 20 \mathrm{~g} / \mathrm{kg} \\
\text { source: commercial product } \\
\text { form: powder } \\
\text { duration: } 17-27 \text { days }\end{array}$ & $\begin{array}{l}\text { - lower body weight and FCR } \\
\text { - lower lactate dehydrogenase, aspartate aminotransferase } \\
\text { and alanine aminotransferase in serum } \\
\text { - higher relative weight of intestine }\end{array}$ & [142] \\
\hline \multicolumn{4}{|l|}{ Laying hens } \\
\hline Essential oil (peppermint) & $\begin{array}{l}\text { Type: Bovans Brown laying hens } \\
\text { dose: 0, 74, 148, 222, and } 296 \mathrm{mg} / \mathrm{kg} \\
\text { source: dry leaf extract (Mentha } \\
\text { piperita) } \\
\text { form: liquid } \\
\text { duration: } 32-44 \text { weeks }\end{array}$ & $\begin{array}{l}\text { - higher Fl, egg production, egg weight, egg mass, } \\
\text { eggshell thickness, and haugh unit } \\
\text { - higher CP, EE and P digestibility } \\
\text { - higher TP in serum } \\
\text { - lower serum cholesterol }\end{array}$ & [143] \\
\hline Essential oil & $\begin{array}{l}\text { Type: Hy-line Brown layer dose: 0, 200, } \\
400 \text { and } 600 \mathrm{mg} / \mathrm{kg} \\
\text { source: star anise (Illicium verum) } \\
\text { form: liquid } \\
\text { duration: 29-31weeks }\end{array}$ & $\begin{array}{l}\bullet \text { higher CP, OM digestibility } \\
\bullet \text { higher metabolic efficiency of lysine, methionine, arginine, } \\
\text { and threonine } \\
\bullet \text { no effects on DM, EE and GE retention }\end{array}$ & [144] \\
\hline Thymol and carvacrol & $\begin{array}{l}\text { Type: Bovans-White } \\
\text { dose: } 1000 \mathrm{mg} / \mathrm{kg} \text { each } \\
\text { source: Thymbra spicata and } \\
\text { Rosemarinus officinalis extract } \\
\text { form: dry leaf powder } \\
\text { duration: } 48-56 \text { weeks }\end{array}$ & $\begin{array}{l}\text { - lower TC and TG in serum } \\
\text { - lower egg production and egg weight } \\
\text { • no effects on FCR, egg shell thickness, yolk color and } \\
\text { haugh unit }\end{array}$ & [145] \\
\hline Polyphenols & $\begin{array}{l}\text { Type: Yueqinhuang laying hens } \\
\text { dose: } 0,0.5,0.8 \text { and } 1.2 \mathrm{~g} / \mathrm{kg} \\
\text { source: eucalyptus leaves } \\
\text { form: extract powder } \\
\text { duration: } 35-44 \text { weeks }\end{array}$ & $\begin{array}{l}\text { - higher egg production, egg mass, egg shell thickness } \\
\text { - lower MDA and cholesterol in egg yolk } \\
\text { - higher GSH-Px, T-SOD, T-AOC in serum } \\
\text { - higher pH at } 45 \text { min with higher redness value of meat } \\
\text { - lower drip loss of meat }\end{array}$ & [146] \\
\hline
\end{tabular}


Table 3 Application of phenolic compounds with major physiological responses in poultry (Continued)

\begin{tabular}{|c|c|c|c|}
\hline Phenolic compounds & Study design & Main findings & Reference \\
\hline Polyphenol & $\begin{array}{l}\text { Type: Hy-line Brown } \\
\text { dose: } 200 \mathrm{mg} / \mathrm{kg} \\
\text { source: commercial (tea polyphenol } \\
\text { and tea catechins) } \\
\text { form: powder } \\
\text { duration: } 65-74 \text { weeks }\end{array}$ & $\begin{array}{l}\text { - higher egg production } \\
\text { - improved FCR } \\
\text { - higher albumen height with haugh unit } \\
\text { - higher protein sulfhydryl content of the albumen } \\
\text { - lower protein carbonyl content and protein surface } \\
\text { hydrophobicity of albumen }\end{array}$ & [147] \\
\hline Essential oil & $\begin{array}{l}\text { Type: Lohmann White } \\
\text { form: powder } \\
\text { source: commercial } \\
\text { dose: } 0,50,100 \text { and } 150 \mathrm{mg} / \mathrm{kg} \\
\text { duration: } 54-65 \text { weeks }\end{array}$ & $\begin{array}{l}\text {-no effects on egg production, egg weight, egg quality, FI } \\
\text { and FCR } \\
\text { - higher CP digestibility } \\
\text { • no effects on energy utilization } \\
\bullet \text { no effects on SFA, MUFA and PUFA composition in egg } \\
\text { yolk }\end{array}$ & [148] \\
\hline Essential oil & $\begin{array}{l}\text { Type: Hy-line layer } \\
\text { form: fine granulates powder } \\
\text { source: oregano dry herbs } \\
\text { dose: } 50,100 \text { and } 150 \mathrm{mg} / \mathrm{kg} \\
\text { duration: } 30-37 \text { weeks }\end{array}$ & $\begin{array}{l}\text { - no effects on egg shell weight, yolk index and haugh unit } \\
\text { - lower crypt depth and higher villus height with villus } \\
\text { height to crypt depth ratio of duodenum } \\
\text { - higher gene expression on glucose transporter 2, peptide } \\
\text { transporter 1, sodium-glucose cotransporter } 1 \text { in duode- } \\
\text { num and jejunum }\end{array}$ & [49] \\
\hline Essential oil mixture & $\begin{array}{l}\text { Type: Hy-line White } \\
\text { dose: 0, } 100 \text { and } 200 \mathrm{mg} / \mathrm{kg} \\
\text { source: Thymus vulgaris, Mentha } \\
\text { piperita, Rosmarinus officinalis and } \\
\text { Anethum graveolens } \\
\text { form: powder } \\
\text { duration: } 40-51 \text { weeks }\end{array}$ & $\begin{array}{l}\text { - lower TC, TG, AST, ALT, in serum } \\
\text { - lower MDA in serum and liver sample } \\
\text { - higher eggshell hardness and thickness }\end{array}$ & [149] \\
\hline Essential oil (peppermint/thyme) & $\begin{array}{l}\text { Type: Lohmann LSL-lite } \\
\text { dose: } 0 \text { and } 1000 \mathrm{mg} / \mathrm{kg} \text { each } \\
\text { source: dry herb extracts } \\
\text { form: powder } \\
\text { duration: } 40-48 \text { weeks }\end{array}$ & $\begin{array}{l}\text { - higher egg production, egg mass } \\
\text { - lower FCR } \\
\text { - higher egg shell thickness, haugh unit } \\
\text { - lower serum cholesterol }\end{array}$ & [150] \\
\hline Thyme and fennel & $\begin{array}{l}\text { Type: Hy-Line White } \\
\text { dose: } 0 \text { and } 40 \mathrm{mg} / \mathrm{kg} \text { each } \\
\text { source: dry herbs (Thymus vulgaris and } \\
\text { Foeniculum vulgare) } \\
\text { form: alcoholic extracts } \\
\text { duration: } 26-38 \text { weeks }\end{array}$ & $\begin{array}{l}\text {-higher egg weight and egg mass } \\
\text { • higher egg yolk color } \\
\text { •lower egg yolk cholesterol } \\
\text { •improve egg yolk omega-3 fatty acid }\end{array}$ & [151] \\
\hline Essential oil & $\begin{array}{l}\text { Type: White leghorn (Lohman) } \\
\text { dose: } 24 \mathrm{mg} / \mathrm{kg} \\
\text { source: oregano dry herbs } \\
\text { form: powder } \\
\text { duration: } 82-106 \text { weeks }\end{array}$ & $\begin{array}{l}\text {-higher egg production with lower FCR in forced molted } \\
\text { hens } \\
\text { - higher SOD value and lower MDA value in liver sample }\end{array}$ & [125] \\
\hline Thymol & $\begin{array}{l}\text { Type: Hi-sex Brown } \\
\text { source: Thymus vulgaris dry herb } \\
\text { form: powder } \\
\text { dose: } 3,6 \text { and } 9 \mathrm{~g} / \mathrm{kg} \\
\text { duration: } 36-52 \text { weeks }\end{array}$ & $\begin{array}{l}\text { - no effects on FI, ADG and FCR } \\
\text { - higher egg weight } \\
\text { - higher SOD, GSH-PX and lower MDA in serum } \\
\text { - higher IgG in serum } \\
\text { - lower LDL-C in serum }\end{array}$ & [152] \\
\hline Essential oil & $\begin{array}{l}\text { Type: Lohmann LSL-lite laying hens } \\
\text { dose: } 40 \mathrm{mg} / \mathrm{kg} \\
\text { source: cinnamon bark } \\
\text { form: powder } \\
\text { duration: } 42-50 \text { weeks }\end{array}$ & $\begin{array}{l}\text { - higher egg production, egg weight and egg mass } \\
\text { •no effects on Fl and body weight } \\
\text { • no effects on TC,TG, uric acid and albumin content in } \\
\text { serum }\end{array}$ & [153] \\
\hline $\begin{array}{l}\text { Fennel (anethole, fenchone and } \\
\text { estragole) }\end{array}$ & $\begin{array}{l}\text { Type: White leghorn } \\
\text { dose: } 0,10 \text { and } 20 \mathrm{~g} / \mathrm{kg} \\
\text { source: fennel fruits (Foeniculum } \\
\text { vulgare) } \\
\text { form: dry fruit powder } \\
\text { duration: } 42-46 \text { weeks }\end{array}$ & $\begin{array}{l}\text { - lower serum MDA } \\
\text { - lower TC and TG in egg yolk }\end{array}$ & [154] \\
\hline Polyphenols & $\begin{array}{l}\text { Type: Hy-line White (Leghorn) } \\
\text { dose: } 0,2.5,5,7.5 \text { and } 10 \mathrm{~g} / \mathrm{kg} \\
\text { source: Echinacea purpurea } \\
\text { form: dry leaf extract powder }\end{array}$ & $\begin{array}{l}\text { - higher egg production and egg mass } \\
\text { - lower TC, TG, in serum } \\
\text { - lower cholesterol in egg yolk } \\
\text { - higher HDL in serum }\end{array}$ & [155] \\
\hline
\end{tabular}


Table 3 Application of phenolic compounds with major physiological responses in poultry (Continued)

\begin{tabular}{ll}
\hline Phenolic compounds & Study design \\
\hline $\begin{array}{l}\text { Peppermint/ menthol/ } \\
\text { menthone/ isomenthone/ }\end{array}$ & Type: Hy-line Brown \\
menthyl acetate/ cineol & dose: $0,5,10,15$ and $20 \mathrm{~g} / \mathrm{kg}$ \\
& $\begin{array}{l}\text { source: dry herb (Mentha piperita) } \\
\text { form: leaves powder } \\
\text { duration: } 64-76 \text { weeks }\end{array}$ \\
& Type: ATAK-S laying hens \\
Essential oil mixture (carvacrol, & dose: 0, 3 and 6 mg/kg \\
thymol, 1:8-cineole, p-cymene & source: commercial \\
and limonene) & form: powder \\
& duration: $52-68$ weeks \\
& Type: Lohmann LSL-white \\
Thyme & dose: 0, 0.1\%, 0.5\% and 1\% \\
& source: dry herbs (Thymus vulgaris) \\
& form: powder \\
& duration: $24-36$ weeks
\end{tabular}

Main findings

Reference

- higher Fl, egg production, egg weight, egg mass,

eggshell thickness, haugh unit

- lower FCR

- lower serum cholesterol

-higher TP in serum

- no effects on $\mathrm{Fl}$, egg production, egg weight and FCR

- no effects on glucose, TC and TG in serum

- no effects on antibody titers against NDV, IB and IBDV

- higher egg production with lower FCR

- decrease concentration of $E$. coli in feces

\section{Other birds}

Polyphenol (resveratrol)

Thymol

Essential oil

Phenolic compounds (peppermint)

Polyphenols (saponins, flavonoids)

Thymol

Polyphenols (anthocyanidins, catechins)

Essential oil (oregano oil)
Type: quail

dose: 0, 200 and $400 \mathrm{mg} / \mathrm{kg}$

source: dry herbs (Polygonum

cuspidatum)

form: powder

duration: 4-16 weeks

Type: quail (female)

dose: 2 g/kg (80 mg/bird per day)

source: commercial

form: powder

duration:100-130 days

Type: quail breeder

dose: $250 \mathrm{mg} / \mathrm{kg}$

source: dry herbs (Trachyspermum

ammi and Anethum graveolens)

form: powder

duration: 8-18 weeks

Type: quail

dose: 10, 20, 30 and $40 \mathrm{~g} / \mathrm{kg}$

source: dry herbs (Mentha piperita)

form: powder

duration: 7-35 days

Type: Japanese quail

dose: $0,1 \%, 3 \%$ and 5\%

source: dry herbs (Astragalus

membranaceus)

form: powder

duration: 0 -35 days

Type: quail

dose: $0,2,4$ and $6.5 \mathrm{~g} / \mathrm{kg}$

source: commercial

form: powder

duration: 85-128 days

Type: duckling (Pekin- female)

dose: $0,0.1 \%$ and $0.2 \%$

source: grape seed extract

form: powder

duration: 0-6 weeks

Type: duckling (Cherry valley)

dose: 150 and $300 \mathrm{mg} / \mathrm{kg}$

source: commercial-oregano (5\% thy-

mol, 65\% carvacrol and 30\% carrier)

form: powder

duration:11-42 days
- no effects on $\mathrm{Fl}$, egg production

-no effects on vitamin A concentration in serum and egg yolk

-higher vitamin E in serum

- lower MDA in serum and egg yolk

- no effects on corticosterone concentrations in plasma

-higher albumen, glucose, globulins, TP in plasma

- higher inflammatory responses

-higher heterophil to lymphocyte ratio in blood

- no effects on egg production

-improved FCR

- no effects on TG, glucose and HDL in serum

- lower TC in serum

- higher number of Lactobacillius in cecum

- no effects on $E$. coli number in cecum

- no effects of FI and ADG

- higher length of small intestine, villus height, villus width,

crypt depth, and villus area

- higher lactic acid bacteria in ileum

- lower Escherichia coli in ileum

- no effects of inner organs weight

- higher Fl, and weight gain

-higher weight of thymus gland and bursa of fabricius

- higher IgA, C3, C4 in serum

- higher T-AOC, GSH-Px, CAT in serum

- higher Lactobacillius and bifidobacterium in intestine

- lower Escherichia number in intestine

- no effects on TP, TC, TG, AST, and ALT in serum

- lower SFA in egg yolk

- higher PUFA in egg yolk

- no effects on body weight gain, $\mathrm{Fl}$, egg production, and egg weight

-higher ADG, and final body weight with improved FCR -higher SOD, GSH-Px, T-AOC, CAT, IgG, IL-2 and lower

MDA in serum

- lower abdominal fat

- lower ileal Escherichia coli but higher ileal Lactobacilli

- no effects on final body weight, ADG, Fl, and FCR

- lower number of coliform bacterial in cecum

-no effects on TC, TG, AST, ALT, glucose, and TP in serum
[156] 
Table 3 Application of phenolic compounds with major physiological responses in poultry (Continued)

\begin{tabular}{|c|c|c|c|}
\hline Phenolic compounds & Study design & Main findings & Reference \\
\hline Essential oil (oregano oil) & $\begin{array}{l}\text { Type: duckling (Cherry valley) } \\
\text { dose: } 100 \mathrm{mg} / \mathrm{kg} \\
\text { source: commercial (oregano oil) } \\
\text { form: powder } \\
\text { duration:1-35 days }\end{array}$ & $\begin{array}{l}\text { - no effects on ADG, FCR, DM, CP, EE, Ash and GE } \\
\text { digestibility } \\
\text { - higher villus height to crypt depth ratio in jejunum } \\
\text { - higher SOD in serum and T-AOC in jejunum mucosa } \\
\text { - lower MDA in serum and liver tissue } \\
\text { - decreased mRNA expression of ZO-3 and slgA }\end{array}$ & [164] \\
\hline Thymol & $\begin{array}{l}\text { Type: turkey poults } \\
\text { dose: } 30 \mathrm{mg} / \mathrm{kg} \\
\text { source: commercial extract } \\
\text { form: powder } \\
\text { duration: } 180-236 \text { days }\end{array}$ & $\begin{array}{l}\text { - improved FCR } \\
\text { - no effects on ADG, lactic acid bacteria and coliform count } \\
\text { in crop, ileum and cecum } \\
\text { - lower MDA level in liver, thigh and breast muscle } \\
\text { - higher GSH-Px, GST activities in liver, thigh and breast } \\
\text { muscle }\end{array}$ & [165] \\
\hline Mixed essential oil & $\begin{array}{l}\text { Type: turkey } \\
\text { dose: } 1 \mathrm{~mL} / \mathrm{L} \\
\text { source: commercial extract } \\
\text { form: liquid } \\
\text { duration: } 175-178 \text { days }\end{array}$ & $\begin{array}{l}\text { - higher percent of } \mathrm{CD} 4^{+} \mathrm{T} \text { lymphocytes in the thymus and } \\
\text { the spleen } \\
\text { - higher percent of } \mathrm{CD} 8^{+} \mathrm{T} \text { lymphocytes in the cecal tonsils } \\
\text { and the blood } \\
\text { - higher percent of } \mathrm{CD} 4^{+} \mathrm{CD} 8^{+} \mathrm{T} \text { lymphocytes in the } \\
\text { thymus and ileal mucosa }\end{array}$ & {$[166]$} \\
\hline Mixed essential oil & $\begin{array}{l}\text { Type: turkey } \\
\text { dose: } 0.3 \mathrm{~g} / \mathrm{kg} \\
\text { source: commercial } \\
\text { form: powder } \\
\text { duration: } 0-140 \text { days }\end{array}$ & $\begin{array}{l}\text { - no effects on ADG, FCR and carcass weight } \\
\text { - lower pH of crop content } \\
\text { - higher a-glucosidase in the ileal digesta } \\
\text { - no effects on SCFA production in the caeca }\end{array}$ & [167] \\
\hline
\end{tabular}

The replacement of $50 \%$ dietary vitamin $E$ with polyphenols did not alter the growth performance but could improve the antioxidant status of sows or their offspring [73]. In piglets, dietary supplementation of polyphenol mixture originated from apples, grape seeds, green tea leaves and olive leaves could reduce plasma MDA value [74]. In a recent study, diets supplemented with grape seed procyanidins as phenolic compounds at $40 \mathrm{mg} / \mathrm{kg}$ could successfully enhance the resistance to weanling stress via increasing the expression of GSH-Px, SOD and CAT genes related with antioxidant in liver and could decrease MDA level in serum, liver and muscle tissue [75].

\section{Phenolic compounds on immune function}

Phenolic compounds originated from various aromatic plants have been proved as immune enhancing role. The anti-inflammatory function of phenolic compounds has become great interest due to their suppressive role of inflammatory prostaglandins and nitric oxide production that could decrease inflammatory process [30]. Phenolic compounds possess anti-inflammatory properties which is one of the major aim to use phenolic compounds as feed additives in farm animal's diets [76]. The basic mode of action of phenolic compounds on immune function is to produce immunoglobulin and secretion of cytokine, increase phagocytosis, and bolstering to release of interferon-y [1]. Polyphenols could active mononuclear cells and could increase phagocytic response by influencing MAPK and nuclear factor $\mathrm{\kappa B}(\mathrm{NF}-\mathrm{kB})$ signaling pathways [76]. The phenolic compounds enhanced the duodenal function and nutrient absorption which promote higher immune status and ultimate growth in broilers [77, 78]. Dietary polyphenols could improve the gut health and immunity of monogastric animals by stimulating immunoglobulins as well as hindering the secretion of proinflammatory cytokines [79]. In addition, the phenolic compounds can play over-expression of antioxidant enzymes, that might down-regulate the inflammation [80]. Different flavonoids and terpenoids have noted to own anti-inflammatory properties [81]. The antiinflammatory properties of essential oils have been reported for their interaction with signaling cascades involving various cytokines and regulatory transcription factors as well as for their pro-inflammatory gene expression capacities [76, 82]. Similarly, different alkaloids (isoquinoline, acetylsalicylic acid) have also been proved as anti-inflammatory role because those could decrease the expression of pro-inflammatory cytokines $[76,83]$. Those alkaloids enriched with phenolic compounds can play a role on gut health by affecting the inflammation cascade with the inhibition of the NF$k B$ activation [76]. Higher cellular and humoral immune response was found in broilers fed with essential oil of thymol and carvacrol [41, 84]. Plant flavonoids genistein $(5 \mathrm{mg} / \mathrm{kg})$ and hesperidin $(20 \mathrm{mg} /$ $\mathrm{kg}$ ) have applied in lipopolysaccharide (LPS) challenged broilers and showed to be effective role on immune-stimulation and improved gut morphology [85]. Moreover, the immunomodulatory function of plant polyphenol has been reported via dropping the expression of interleukins IL-4, IL-13, IL-18 and IFN$\gamma$ in LPS challenged broilers fed with phenolic rich diets [86]. Dietary supplementation of saponins, 
phenolic compounds originated from soapnut (Sapindus mukorossi) at $150 \mathrm{mg} / \mathrm{kg}$ could improve the cellmediated and humoral immune response of broilers without adverse effects on optimum body weight [87]. Inclusion of thyme essential oil at $3 \mathrm{~g} / \mathrm{kg}$ could improve serum IgG, IgA, antibody titer against ND vaccine in broilers and could eliminate the adverse effects of ochratoxin $A$ and aflatoxin $B_{1}$ in broiler diets [88]. In broilers challenged with LPS, dietary supplementation of carvacrol essential oils as phenolic compound at $200 \mu \mathrm{L} / \mathrm{L}$ could prevent the expression of inflammatory cytokines that ensured the antiinflammatory role of carvacrol in broilers [89]. In a recent study, resveratrol a phenolic compound at 500 $\mathrm{mg} / \mathrm{kg}$ could regulate the immune function and inflammatory response, by inhibiting different signaling pathways like NF-kB, MAPK, and PI3K/AKT caused by heat stress in yellow feather broilers [90]. In addition, higher expression of $\mathrm{T}$ helper 1 cytokine (interferon- $\gamma$ ) and lower expression of $\mathrm{T}$ helper 2 cytokine (IL-6) were noted in laying hens fed with proanthocyanidin-rich extract from Pinus radiata bark $(20 \mathrm{mg} / \mathrm{kg})$ [91]. The author finally stated that proanthocyanidin had an immunomodulatory effect in chickens. Higher monocyte counts in hens fed with fennel essential oil at $300 \mathrm{mg} / \mathrm{kg}$ [92] and increased number of lymphocyte with thyme powder at $0.2 \%$ were reported as good health indicators in laying hens [93]. Due to the extended production life and long vaccination schedules of the laying hens from day-old to curled age may have an indirect role on supporting the immune function with phenolic compounds in diets [94]. Laying hens fed with mixed essential oil originated from Thymus vulgaris, Mentha piperita, Rosmarinus offisinalis and Anethum graveolens at 200 $\mathrm{mg} / \mathrm{kg}$ could improve antibody response against ND vaccine and SRBC [95].

Piglets fed with polyphenolic rich diets showed lower expression of different pro-inflammatory genes in duodenum, ileum and colon than the control diets [96]. In addition, dietary supplementation of phenolic rich soy isoflavones showed improve immune function with lower diarrhea rate, and lower concentrations of endotoxin in plasma of piglets challenged with LPS [97]. A significantly lower inflammatory mediators NF- $\mathrm{KB}$ and Nrf2 in duodenal mucosa resulted in lower risk of intestinal diseases was also reported in pigs fed with phenolic rich supplemented diets containing grape seed and grape pomace extract [98]. In a trail for piglets subjected to oxidative stress (diquat injection, intraperitoneal) showed tea polyphenols could influence the activities of $\mathrm{T}$ lymphocyte, increased the ratio of $\mathrm{CD}^{+} / \mathrm{CD}^{+}$ ensured the recovery activities of immune damages caused by oxidative stress. Further it could enhance the cell-mediated immune response and reduce the secretion of pro-inflammatory cytokines such as IFN- $\gamma$, which ensured the immunomodulatory role of tea polyphenols [99]. The mechanism for selective inhibition of IFN $-\gamma$ signaling, by downregulating $\mathrm{STAT}_{1}$ activation and $\mathrm{T}$ bet expression of CD4 $(+) \mathrm{T}$ cell in colonic lamina propria. In a recent study, dietary supplementation of tea polyphenol at $100 \mathrm{mg} / \mathrm{kg}$ in piglets could improve the intestinal mucosal immunity via increasing the content of IL-2, IL-10 in jejunum and ileum as well as activated the Notch2 signaling pathway in small intestine [100].

\section{Phenolic compounds on lipid metabolism}

The anticholesteremic effects of phenolic compounds has been proved in different in vivo trails. For example, Park et al. [101] has applied rutin and tannic acid as phenolic compounds in rats to evaluate the lipid metabolism and observed that both phenolic compounds could significantly reduce the cholesterol level in plasma and liver. It was hypothesized that supplemented phenolic compounds stimulated the excretion of fecal sterols, and reduced absorption of dietary cholesterol which resulted lower plasma and hepatic cholesterol. Similarly, supplementation of phenolic compounds as feed additives in farm animal diets has shown positive effects against lipid oxidation [30]. Lower plasma total cholesterol (TC), LDL-C were reported in broilers fed with thyme (Thymus vulgaris) extract at $0.2 \%$ to $0.6 \%$ diets and the decrease rate were $36 \%$ to $40 \%$ for TC and $63 \%$ to $70 \%$ for LDL-C [102]. Broilers diets supplemented with thymol; tannic acid and gallic acid showed about $12 \%$ lower TC in liver and higher PUFA in breast muscle [10]. In addition, about $10 \%$ lower total lipid, triglycerides and about 22\% lower cholesterol were found in broilers offered polyphenol rich grape seed at 10 to $40 \mathrm{~g} / \mathrm{kg}$ diets [43]. The bioflavonoids (genistein and hesperidin) could improve the fatty acid composition and lipid metabolite in broilers [103]. In breeder quail, fed with dill essential oil (Anethum graveolens L.) at $250 \mathrm{mg} / \mathrm{kg}$ diets could reduce about $21.52 \%$ total cholesterol (TC) in serum [104]. The mode of action of polyphenol on cholesterol reduction is that it contains multiple phenolic compounds which inhibit the oxidation of cholesterol resulted lower deposition of lipids in blood vessels. Furthermore, it prevents the oxidation of unsaturated fatty acids resulted lower deposition of cholesterol in serum and maintenance a good balance of normal entry and exit of lipids in blood vessel and thus have an anticholesteremic effects [69].

\section{Phenolic compounds on antimicrobial function}

The antimicrobial role of pohenolic compounds originated from aromatic plants and their derivatives have been described by several scientists $[105,106]$. Phenolic 
Table 4 Application of phenolic compounds with major physiological responses in swine

\begin{tabular}{|c|c|c|c|}
\hline $\begin{array}{l}\text { Phenolic } \\
\text { compounds }\end{array}$ & Study design & Main findings & Reference \\
\hline $\begin{array}{l}\text { Polyphenols } \\
\text { (procyanidins) }\end{array}$ & $\begin{array}{l}\text { Type: crossbred piglets (Duroc } \times \text { Landrace } \times \\
\text { Yorkshine) } \\
\text { dose: } 50,100 \text { and } 150 \mathrm{mg} / \mathrm{kg} \\
\text { source: commercial (grape seed procyanidins) } \\
\text { form: powder } \\
\text { duration: } 1-28 \text { days }\end{array}$ & $\begin{array}{l}\text {-higher maltase and sucrase in jejunum mucosa } \\
\text { - lower urea nitrogen, diamine oxidase, endotoxin in blood } \\
\text { - lower digestibility of DM, GE, and CP } \\
\text {-decreased lipase and amylase activities of pancreas and } \\
\text { duodenum }\end{array}$ & [168] \\
\hline Polyphenols & $\begin{array}{l}\text { Type: weaned piglets (Songliao black pigs) } \\
\text { dose: } 5 \% \\
\text { source: grape pomace } \\
\text { form: powder } \\
\text { duration: } 28-56 \text { days }\end{array}$ & $\begin{array}{l}\text {-no effects on ADG, FI, and FCR } \\
\text { - higher number of Lactobacillus delbrueckii, Olsenella umbonata } \\
\text { and Selenomonas bovis in caecum } \\
\text { - higher villus height and villus height/crypt depth ratio of jejunum } \\
\text { - lower MRNA expression of proinflammatory cytokines (IL-1 } \beta \text {, IL-8, } \\
\text { IL-6 and TNF-a) } \\
\text { - higher IgG in serum }\end{array}$ & [169] \\
\hline $\begin{array}{l}\text { Phenolic } \\
\text { compounds }\end{array}$ & $\begin{array}{l}\text { Type: piglets (Landrace } \times \text { Large White } \times \\
\text { Duroc) } \\
\text { dose: } 9 \% \text { solid } \\
\text { source: grape pomace } \\
\text { form: silage } \\
\text { duration: } 20-50 \text { days }\end{array}$ & $\begin{array}{l}\text { - higher ADG and final body weight } \\
\text { - higher GSH, } \mathrm{H}_{2} \mathrm{O}_{2} \text { and TAC in intestinal tissue } \\
\text { - decreased in TBARS and CARB in intestinal tissue } \\
\text { - higher lactic acid bacteria and Bifidobacteria in feces } \\
\text { - lower Enterobacteriacae and Campylobacter jejuni in feces } \\
\text { - higher n-3 fatty acids in meat } \\
\text { - lower n-6/n-3 ratio in meat }\end{array}$ & [170] \\
\hline Polyphenol & $\begin{array}{l}\text { Type: male finishing pigs (Yorkshire } \times \text { Duroc } \\
\times \text { Landrace) } \\
\text { dose: } 5 \% \\
\text { source: fermented apple pomace } \\
\text { form: silage } \\
\text { duration: } 53 \text { days }\end{array}$ & $\begin{array}{l}\text { - no effects on ADG, and final body weight } \\
\text { - lower DM intake with higher FCR } \\
\text { - no effects on carcass weight, and back fat thickness } \\
\text { - higher moisture content with lower ash and water holding } \\
\text { capacity of meat } \\
\text { - higher linoleic acid (C18:2n-6), linolenic acid (C18:3) and arachidic } \\
\text { acid (C20:0) and total PUFA in back fat } \\
\text { - lower palmitic acid (C16:0), palmitoleic acid (C16:1) and } \\
\text { heptadecenoic acid (C17:1) }\end{array}$ & {$[171]$} \\
\hline Procyanidins & $\begin{array}{l}\text { Type: piglets (Duroc } \times \text { Landrace } \times \text { Yorkshine) } \\
\text { dose: } 50,100 \text { and } 150 \mathrm{mg} / \mathrm{kg} \\
\text { source: grape seed extract } \\
\text { form: powder } \\
\text { duration: } 0-28 \text { days }\end{array}$ & $\begin{array}{l}\text { - no effects on body weight gain, Fl, and FCR } \\
\text {-decreased diarrhea rate } \\
\text { •higher IgG, IgM, C-4, IL-2, T-AOC, SOD, GSH-Px in serum } \\
\text { - lower MDA in serum }\end{array}$ & [172] \\
\hline Tannic acid & $\begin{array}{l}\text { Type: weaned piglets (Duroc } \times \text { Landrace } \times \\
\text { Yorkshine) } \\
\text { dose: } 500,1000 \text { and } 1500 \mathrm{mg} / \mathrm{kg} \\
\text { source: commercial (Chinese gallnut) } \\
\text { form: microencapsulated } \\
\text { duration: } 21-35 \text { days }\end{array}$ & $\begin{array}{l}\text { - no effects on } \mathrm{ADG}, \mathrm{Fl} \text {, and FCR } \\
\text { - lower crypt depth with higher ratio of villus height to crypt depth } \\
\text { of duodenum } \\
\text { - } \text { higher gene expression of solute carrier family } 6 \text {, member } 19 \text { and } \\
\text { solute carrier family } 15 \text {, member } 1 \text { in ileum } \\
\text { - lower gene expression of solute carrier family 5, member } 1 \text { in } \\
\text { jejunum } \\
\text { - lower maltase activities in ileum } \\
\text { •improved colonic bacterial community }\end{array}$ & [173] \\
\hline Tannic acid & $\begin{array}{l}\text { Type: piglets (Landrace } \times \text { Yorkshine } \times \text { Duroc) } \\
\text { source: commercial (chestnut wood, } 75 \% \\
\text { tannins) } \\
\text { dose: } 1000 \mathrm{mg} / \mathrm{kg} \\
\text { form: powder } \\
\text { duration: } 0-28 \text { days }\end{array}$ & $\begin{array}{l}\text { - no effects on ADG, Fl, and FCR } \\
\text { - higher CAT, GSH-Px, IgM and lower MDA in serum } \\
\text { •improved trypsin, lipase and amylase activities } \\
\text { - higher villus height of jejunum } \\
\text { - higher propionic acid, butyric acid, and acetic acid concentrations } \\
\text { in the colon } \\
\text { - lower diarrhea incidence }\end{array}$ & [6] \\
\hline Tannins & $\begin{array}{l}\text { Type: piglets (German Landrace } \times \text { Pietrain) } \\
\text { and in-vitro (cecal fermentation) } \\
\text { dose: } 1.13,2.25,4.5 \mathrm{~g} / \mathrm{kg} \text {; and } 0.75,1.5,3,6 \\
\mathrm{~g} / \mathrm{L} \text { (in vitro) } \\
\text { source: commercial (chestnut wood extract, } \\
75 \% \text { tannins) } \\
\text { form: powder } \\
\text { duration: } 0-28 \text { days }\end{array}$ & $\begin{array}{l}\text { - lower total gas production, concentrations of ammonia and } \\
\text { volatile fatty acids (in vitro) } \\
\text {-improved FCR } \\
\text { - decreased caecal concentrations of ammonia, iso-butyric, and iso- } \\
\text { valeric acid } \\
\text { - higher number of lactobacilli in jejunum }\end{array}$ & [174] \\
\hline Tannic acid & Type: fattening boars (Landrace $\times$ Large & -higher villus height and mucosal thickness in duodenum & [175] \\
\hline
\end{tabular}


Table 4 Application of phenolic compounds with major physiological responses in swine (Continued)

\begin{tabular}{|c|c|c|c|}
\hline $\begin{array}{l}\text { Phenolic } \\
\text { compounds }\end{array}$ & Study design & Main findings & Reference \\
\hline & $\begin{array}{l}\text { White) } \\
\text { source: commercial extract ( } 75 \% \text { tannins) } \\
\text { dose: } 1 \%, 2 \% \text { and } 3 \% \\
\text { form: powder } \\
\text { duration: } 123-193 \text { days }\end{array}$ & - decreased mitosis and apoptosis count in large intestine & \\
\hline $\begin{array}{l}\text { Hydrolysable tannic } \\
\text { acid }\end{array}$ & $\begin{array}{l}\text { Type: Swiss Large White boars } \\
\text { dose: } 15 \mathrm{mg} \text { and } 30 \mathrm{mg} / \mathrm{kg} \\
\text { source: commercial (chestnut) } \\
\text { form: powder } \\
\text { duration: } 105-165 \text { days }\end{array}$ & $\begin{array}{l}\text {-no effects on FI, ADG and carcass traits } \\
\text { • improved feed efficacy } \\
\text { •reduced size of salivary and bulbourethral gland }\end{array}$ & [176] \\
\hline $\begin{array}{l}\text { Polyphenols } \\
\text { (condensed } \\
\text { tannins) }\end{array}$ & $\begin{array}{l}\text { Type: MO25C-barrows (Moura } \times \text { Landrace, } \\
\text { and Large White) } \\
\text { dose: } 10 \% \\
\text { source: grape pomace } \\
\text { form: powder } \\
\text { duration: } 21 \text { days }\end{array}$ & $\begin{array}{l}\text {-no effects on production of thiobarbituric acid } \\
\text { reactive substances in the loin samples } \\
\text { •higher redness value of pork }\end{array}$ & [177] \\
\hline $\begin{array}{l}\text { Hydrolysable tannic } \\
\text { acid }\end{array}$ & $\begin{array}{l}\text { Type: male pigs (Landrace } \times \text { Yorkshire } \times \\
\text { Duroc) } \\
\text { source: commercial (albumin tannate, } 500 \mathrm{~g} \\
\text { TA/kg) } \\
\text { dose: } 125,250,750 \text { and } 1000 \mathrm{mg} / \mathrm{kg} \\
\text { form: powder } \\
\text { duration: } 0-28 \text { days }\end{array}$ & $\begin{array}{l}\text { - reduced ADG but improve FCR } \\
\text { - lower faecal coliform count } \\
\text { - higher excretion of Fe in faeces } \\
\text { - lower total erythrocyte, hemoglobin, and hematocrit in plasma }\end{array}$ & [178] \\
\hline Essential oil & $\begin{array}{l}\text { Type: crossbred piglets (Duroc } \times \text { Landrace } \times \\
\text { Large White) } \\
\text { dose: } 0.025 \% \\
\text { source: commercial }(4.5 \% \text { cinnamaldehyde } \\
\text { and } 13.5 \% \text { thymol) } \\
\text { form: powder } \\
\text { duration: } 0-28 \text { days }\end{array}$ & $\begin{array}{l}\text { - higher } \mathrm{ADG}, \mathrm{DM}, \mathrm{CP} \text {, and energy retention } \\
\text { • higher villus height of jejunum } \\
\text { - lower E. coli and total anaerobes in rectum } \\
\text { • higher albumin, IgA, IgG, and T-AOC in plasma }\end{array}$ & [179] \\
\hline Essential oil & $\begin{array}{l}\text { Type: wined piglets (Duroc } \times \text { Landrace } \times \\
\text { Yorkshire) } \\
\text { dose: } 50,100,150 \mathrm{~g} / \mathrm{t} \\
\text { source: commercial (cinnamaldehyde and } \\
\text { thymol) } \\
\text { form: powder } \\
\text { duration: } 36-71 \text { days }\end{array}$ & $\begin{array}{l}\text { - higher FI, ADG, final body weight } \\
\text { - ower FCR } \\
\text { - decreased diarrhea } \\
\text { - lower E. coli in feces } \\
\text { - higher, IgA, IgG, C3, C4 in blood }\end{array}$ & [180] \\
\hline Essential oil & $\begin{array}{l}\text { Type: wined piglets (Duroc } \times \text { Landrace } \times \\
\text { Yorkshire) } \\
\text { dose: } 30 \mathrm{mg} / \mathrm{kg} \\
\text { source: commercial }(25 \% \text { thymol and } 25 \% \\
\text { carvacrol) } \\
\text { form: powder } \\
\text { duration: } 0-28 \text { days }\end{array}$ & $\begin{array}{l}\text {-higher ADG, DM, CP, Ca, P, and GE digestibility } \\
\text { • higher number of Lactobacilli counts in feces } \\
\text { • higher villi height of duodenum } \\
\text { • higher trypsin and chymotrypsin activities }\end{array}$ & [181] \\
\hline Essential oil & $\begin{array}{l}\text { Type: male pigs (Duroc } \times \text { Landrace } \times \text { Large } \\
\text { White) } \\
\text { dose: } 50,100 \text { and } 200 \mathrm{ppm} \\
\text { source: commercial }(13.5 \% \text { thymol and } 4.5 \% \\
\text { cinnamaldehyde) } \\
\text { form: silage } \\
\text { duration: } 53 \text { days }\end{array}$ & $\begin{array}{l}\text { - higher ADG and DM digestibility } \\
\text { - lower TC, TG in serum } \\
\text { - higher goblet cell and lactase activities in jejunum } \\
\text { - higher ratio of villus and crypt depth in ileum } \\
\text { - higher sucrose activities in duodenum } \\
\text { - higher expression of occluding and glucose transporter-2 gene in } \\
\text { duodenum and ileum }\end{array}$ & [182] \\
\hline
\end{tabular}

compounds showed inhibitory activities against Gram negative and Gram positive bacteria [1]. The mode of action of phenolic compounds behinds their lipophilic nature which can amass in lipid bilayer of bacterial cell membrane and mitochondria, resulted in distracting regular functions [1]. In addition, those compounds could increase the permeability of inner bacterial membrane, decrease ATP production and inhibit the DNA gyrase that involves the mechanism of DNA and RNA synthesis of bacteria. Moreover, phenolic causes cell homeostasis and resulted in cell death by losing ions as the denaturation of cellular protein is responsible for bacterial cell death $[105,107]$. Besides, the antimicrobial role of phenolic compounds is due to their structure. 
The hydroxyl $(-\mathrm{OH})$ groups in phenolic compounds exhibit bactericidal activities [101].

It has been described that dietary supplementation of plant extract or herbs, could effective in counter to intestinal colonization of $E$. coli and Clostridium perfringens due to antimicrobial properties of existing phenolic compounds (carvacrol and thymol) $[108,109]$. In addition, broilers offered with phytogenic feed additives could attenuate the pathogenic effects of Eimeria infection [110, 111]. Moreover, essential oil (oregano oil) originated from different plants have shown effective against gut parasites (Cryptosporidium spp.) [112]. Dandelion herb has been reported to have antibacterial role especially against Staphylococcus aureus and E. coli in poultry [113]. Similarly, broilers diets supplemented with phenolic rich grape concentrate or seed extract could alter intestinal morphology and microbial population [32]. In their studies, higher number of Lactobacillus and Enterococcus spp. in ileal content with lower number of Clostridium was found in broilers. In contrast, broiler chickens supplemented with thyme and oregano could decrease Lactobacillus counts in crop, and small intestine, respectively [39]. However, no significant differences for Lactobacillus count in cecum was noted. The authors justified that the supplementation dosages up to $30 \mathrm{~g} / \mathrm{kg}$ was not enough to alter the gut community in their studies. Decreased number of E. coli in broilers fed with grape seed extract was also recorded [114]. In a recent study, broilers fed with essential oil (thymol) along with organic acid at $0.3 \mathrm{~g} / \mathrm{kg}$ diet could decrease the number of $E$. coli in ileal digesta [115]. The authors justified that the decreased number of $E$. coli could enhance the absorptive capacity of intestine via improving the epithelial cells to regenerate villus area of host. The antimicrobial properties of thyme essential oil against Salmonella spp.; and oregano essential oil against total viable bacteria and Pseudomonas spp. on turkey products have been reported respectively [61, 116]. In very recent study reported that Campylobacter jejuni of chicken can contaminate carcass at slaughter which is responsible for gastroenteritis in humans. However, the colonization effects $C$. jejuni was successfully reduced in broilers fed with carvacrol a phenolic compounds originated from oregano oil (Origanum glandulosum) [117]. A similar finding against Campylobacter colonization in broilers fed with combination of thymol, and carvacrol at $0.5 \%$ level was also recorded [118]. In addition, lower number of Streptococcus spp., Escherichia coli and higher number of Lactobacillus spp. in ileum of broilers fed with grape seed was recorded [43].

Oral administration of 300 or $400 \mu \mathrm{L}$ carvacrol essential oils could reduce Salmonella spp. and Escherichia coli in gut of broilers [47]. Furthermore, the lower number of Clostridium was found in ileum of broilers fed with essential oil (thyme $1.7 \%$ and vanillin $1 \%$ ) at $5 \mathrm{~g} / \mathrm{kg}$ dietary supplementation [119]. In addition, thyme essential oil with benzoic acid at $800 \mathrm{~g} / \mathrm{t}$ diets had bacteriostatic role on Salmonella enteritidis in broilers [120]. Several authors justified that the polyphenolic compounds could enhance bactericidal activities which prevent growth of pathogenic bacteria in intestine where as some beneficial bacteria like Lactobacillus spp. and Bifidobacterium spp. could play a role on metabolism of phenolic compounds that provides energy to cells [32, 121, 122]. Higher number of enteric Bifidobacterium and Lactobacillus spp. whereas the lower number of Escherichia coli and Salmonella were noted in laying hens fed with oregano essential oil at $100 \mathrm{mg} / \mathrm{kg}$ [49]. Laying hens diets supplemented with essential oil (thyme oil) in combination of organic acid at $300 \mathrm{mg} / \mathrm{kg}$ could increase the number of Bifidobacterium spp. in cecal digesta [123]. Similarly, lower number of enteric Escherichia coli was found in laying hen fed thyme at $0.5 \%$ level of supplementation [124]. However, feeding molded laying hen with oregano essential oil at $24 \mathrm{mg} / \mathrm{kg}$ had no any effects on enteric bacterial count which may due to higher aged hens failed to metabolize the active ingredients of test diets [125]. Piglets fed with commercial mixture of phytochemicals showed lower number of fecal Salmonella and E. coli [126] and higher number of Lactobacillus spp. with benzoic acid and thyme supplementation [127]. Furthermore, combination of chestnut wood tannins and organic acids could decrease the harmful $E$. coli and increase the beneficial lactic acid bacteria in piglets during 82 to $127 \mathrm{~d}$ of evaluation [23]. Similarly, piglets fed with polyphenolic rich (grape extract or hop) supplemented diets showed lower number of Clostridium cluster in the faecal microbiota [96]. In a pathogenic challenge trail where piglets were infected with enterotoxigenic $E$. coli offered commercial polyphenol rich diets and the lower diarrhea rate was recorded [128].

The application of phenolic compounds with major physiological responses in poultry and swine were presented in Table 3 and Table 4 respectively.

\section{Conclusions}

Although few studies noted that there were no any significant effects of dietary polyphenols on production performance and health status of farm animals but most of the studies found their efficacy to be used as potential feed additives. Also, irrespective of a large number of studies claiming health-promoting properties of various phenolic compounds, it should be mentioned that not all the phenolic compounds are necessarily beneficial, and their physiological effects depends on a range of factors. The action of phenolic was varied due to different sources, parts of 
plants, degree of maturity, dosages, extraction method, environmental or dietary patterns, metabolism, host species, duration of trail and bioavailability of compounds in some trials. Collectively this review highlighted to use phenolic compounds as a potential natural feed additive which has a role on the antioxidant, immunity, antimicrobial and overall production performance in poultry and swine. To get the advantages form those natural compounds, selected phenolic compound along with optimum level of supplementation should be considered base on specific animal species.

\begin{abstract}
Abbreviations
ADG: Average daily gain; Fl: Feed intake; FCR: Feed conversion ratio; GST: Glutathione-S-transferase; GSH: Reduced glutathione; TBARS: Thiobarbituric acid reactive substances; CARB: Protein carbonyls; MDA: Malondialdehyde; CORT: Corticosterone; TC: Total cholesterol; LDLC: Low-density lipoprotein cholesterol; HDL: High-density lipoprotein; TG: Triglyceride; ALT: Alanine aminotransferase; ALP: Alkaline phosphatase; AST: Aspartate aminotransferase; CRE: Creatinine; SFA: Saturated fatty acid MUFA: Monounsaturated fatty acid; PUFA: Polyunsaturated fatty acid; IBV: Infectious bronchitis virus; IBDV: Infectious bursal disease virus; NDV: Newcastle disease virus; SRBC: Sheep red blood cell; C4: Complement 4; IL: Interleukin; ZO: Zonula occludens; TP: Total protein; P: Phosphorus; DM: Dry matter; CP: Crude protein; EE: Crude fat; GE: Gross energy
\end{abstract}

\section{Acknowledgements}

The first author SM acknowledges the postdoctoral fellowship support from China Agricultural University, Beijing-100193, China.

\section{Authors' contributions}

SM wrote the manuscript. XP, QS, and SM revised and finalized the manuscript. All authors read and approved the final manuscript.

\section{Funding}

This research received no external funding.

\section{Availability of data and materials}

Not applicable.

\section{Ethics approval and consent to participate}

Not applicable.

\section{Consent for publication}

Not applicable.

\section{Competing interests}

The authors declare that they have no competing interests relevant to this publication.

Received: 28 September 2020 Accepted: 26 January 2021

Published online: 07 April 2021

\section{References}

1. Christaki E, Giannenas I, Bonos E, Florou-Paneri P. Chapter 2-Innovative uses of aromatic plants as natural supplements in nutrition. In: Florou-Paneri P, Christaki E, Giannenas I, editors. Feed Additives. London: Academic Press; 2020. p. 19-34.

2. Dykes L, Rooney L. Phenolic compound in ceral grains and their health benefits. Cereal Foods World. 2007;52(3):105-11.

3. Hung P. Phenolic compounds of cereals and their antioxidant capacity. Crit Rev Food Sci Nutri. 2016;56(1):25-35.

4. Franz CM, Baser KHC, Hahn-Ramssl I. Chapter 3-Herbs and aromatic plants as feed additives: Aspects of composition, safety, and registration rules. In: Florou-Paneri P, Christaki E, Giannenas I, editors. Feed Additives. London: Academic Press; 2020. p. 35-56.
5. Smulikowska S, Pastuszewska B, Swiech E, Ochtabin A, Mieczkowska A Nguyen VC, et al. Tannin content affects negatively nutritive value of pea for monogastrics. J Anim Feed Sci. 2001;10:511-23.

6. Liu H, Hu J, Mahfuz S, Piao X. Effects of hydrolysable tannins as zinc oxide substitutes on antioxidant status, immune function, intestinal morphology, and digestive enzyme activities in weaned piglets. Animals. 2020a;10(5):757.

7. Schiavone A, Guo K, Tassone S, Gasco L, Hernandez E, Denti R, Zoccarato I. Effects of a natural extract of chestnut wood on digestibility, performance traits, and nitrogen balance of broiler chicks. Poult Sci. 2008;87:521-7.

8. Kumar R, Vaithiyanathan S. Occurrence, nutritional significance and effect on animal productivity of tannins in tree leaves. Anim Feed Sci Technol. 1990; 30:21-38.

9. Liu HW, Li K, Zhao JS, Deng W. Effects of chestnut tannins on intestinal morphology, barrier function, proinflammatory cytokine expression, microflora and antioxidant capacity in heat stressed broilers. J Anim Physiol Anim Nutr. 2018a;102:717-26.

10. Starcevic K, Krstulović L, Brozić D, Maurić M, Stojević Z, Mikulec Ž, et al. Production performance, meat composition and oxidative susceptibility in broiler chicken fed with different phenolic compounds. J Sci Food Agric. 2015;95(6):1172-8

11. Furukawa S, Fujita $T$, Shimabukuro $M$, Iwaki $M$, Yamada $Y$, Nakajima $Y$, et al. Increased oxidative stress in obesity and its impact on metabolic syndrome. LWT-Food Sci Technol. 2004;114.

12. Vuolo MM, Lima VS, Maróstica Junior MR. Chapter 2-Phenolic compounds: structure, classification, and antioxidant power. In: MRS C, editor. Bioactive Compounds. Duxford: Woodhead Publishing; 2019. p. 33-50.

13. Kannan G, Heath JL, Wabeck CJ, Mench JA. Shackling of broilers: Effects on stress responses and breast meat quality. Br Poult Sci. 1997;38:323-32.

14. Xing T, Gao F, Tume RK, Zhou G, Xu X. Stress effects on meat quality: A mechanistic perspective. Compr Rev Food Sci Food Saf. 2019;18(2):380-401.

15. Jin LZ, Dersjant-Li Y, Giannenas I. Chapter 10-Application of aromatic plants and their extracts in diets of broiler chickens. In: Florou-Paneri P, Christaki E, Giannenas I, editors. Feed Additives. London: Academic Press; 2020. p. 159-85.

16. Mahfuz S, He T, Liu S, Wu D, Long S, Piao XS. Dietary inclusion of mushroom (Flammulina velutipes) stem waste on growth performance, antibody response, immune status, and serum cholesterol in broiler chickens. Animals. 2019;9:692.

17. Long S, Liu L, Liu S, Mahfuz S, Piao X. Effects of Forsythia suspense extract as an antibiotics substitute on growth performance, nutrient digestibility, serum antioxidant capacity, fecal Escherichia coli concentration and intestinal morphology of weaned piglets. Animals. 2019;9:729.

18. Castrica M, Rebucci R, Giromini C, Tretola M, Cattaneo D, Baldi A. Total phenolic content and antioxidant capacity of agri-food waste and byproducts. Ital J Anim Sci. 2019;18(1):336-41.

19. Rosa LA, Moreno-Escamilla JO, Rodrigo-García J, Alvarez-Parrilla E. Chapter $12-$ Phenolic Compounds. In: Yahia EM, editor. Postharvest Physiology and Biochemistry of Fruits and Vegetables. Duxford: Woodhead Publishing; 2019. p. 253-71

20. Puvaca N, Ljubojevic D, Kostadinovic L, Levic J, Nikolova N, Miscevi C, et al. Spices and herbs in broilers nutrition: hot red pepper (Capsicum annuum L.) and its mode of action. World's Poult Sci J. 2015;71(4):683-8.

21. Jiang J, Xiong Y. Natural antioxidants as food and feed additives to promote health benefits and quality of meat products: a review. Meat Sci. 2016;120: 107-17.

22. Liu HS, Mahfuz SU, Wu D, Shang QH, Piao XS. Effect of chestnut wood extract on performance, meat quality, antioxidant status, immune function, and cholesterol metabolism in broilers. Poult Sci. 2020b;99(9):4488-95.

23. Brus M, Dolinsek J, CenCic A, Skorjanc D. Effect of chestnut (Castanea sativa Mill.) wood tannins and organic acids on growth performance and faecal microbiota of pigs from 23 to 127 days of age. Bulgarian J Agri Sci. 2013;19:841-7.

24. Ouyang $X$, Huang $X$, Boot MD, Hensen EJM. Efficient conversion of pine wood lignin to phenol. ChemSusChem. 2020;13(7):1705-9.

25. Sharopov F, Braun MS, Gulmurodov I, Khalifaev D, Isupov S, Wink M. Antimicrobial, antioxidant, and anti-inflammatory activities of essential oils of selected aromatic plants from Tajikistan. Foods. 2015;4:645-53.

26. Pandini JA, Pinto FGS, Scur MC, Santana CB, Costa WF, Temponi LG. Chemical composition, antimicrobial and antioxidant potential of the essential oil of Guarea kunthiana A. Juss. Braz J Biol. 2018;78:53-60.

27. Vogt H, Harnisch S, Rauch HW, Heil G. (Der Einsatz von Naturstoffen Heilund Gewürzpflanzen) im Geflügelmastfutter (Dried natural spices in broiler rations). Arch Geflügelk. 1989;53:144-50. 
28. Zhong X, Shi Y, Chen J, Xu J, Wang L, Beier RC, et al. Polyphenol extracts from Punica granatum and Terminalia chebula are anti-inflammatory and increase the survival rate of chickens challenged with Escherichia coli. Bio Pharma Bull. 2014;37:1575-82.

29. Hashemi S, Davoodi H. Herbal plants and their derivatives as growth and health promoters in animal nutrition. Vet Res Commun. 2011;35:169-80.

30. Valenzuela-Grijalva NV, Pinelli-Saavedra A, Muhlia-Almazan A, DominguezDiaz D, Gonzalez-Rios H. Dietary inclusion effects of phytochemicals as growth promoters in animal production. J Anim Sci Technol. 2017;59:8.

31. Mountzouris KC, Paraskevas V, Tsirtsikos P, Palamidia I, Steiner T, Schatzmayr $\mathrm{G}$, et al. Assessment of a phytogenic feed additive effect on broiler growth performance, nutrient digestibility and caecal microflora composition. Anim Feed Sci Technol. 2011;168:223-31.

32. Viveros A, Chamorro S, Pizarro M, Arija I, Centeno C, Brenes A. Effects of dietary polyphenol-rich grape products on intestinal microflora and gut morphology in broiler chicks. Poult Sci. 2011;90:566-78.

33. Yan L, Meng Q, Kim I. The effect of an herb extract mixture on growth performance, nutrient digestibility, blood characteristics and fecal noxious gas content in growing pigs. Livest Sci. 2011;141:143-7.

34. Madsen H, Bertelsen G, Skibsted L. Antioxidative activity of spice extracts. In: Risch SJ, Ho SCT, editors. Spices, flavor, chemistry and antioxidant properties. Washington, DC: American Chemical Society; 1997. p. p176-87.

35. Franz C, Baser KHC, Windisch W. Essential oils and aromatic plants in animal feeding - a European perspective. A review. Flavour Fragrance J. 2010;25:327-40.

36. Gadde U, Kim WH, Oh ST, Lillehoj HS. Alternatives to antibiotics for maximizing growth performance and feed efficiency in poultry: a review. Anim Health Res Rev. 2017;18:26-45.

37. Giannenas I, Bonos E, Christaki E, Florou-Paneri P. Oregano: a feed additive with functional properties. In: Holban AM, Grumezescu AM, editors. Therapeutic Foods, Handbook of Food Engineering, vol. 8. London, UK: Elsevier Academic Press; 2018.

38. Surai P. Polyphenol compounds in the chicken/animal diet: from the past to the future. J Anim Physiol Anim Nutr. 2014;98:19-31.

39. Abdel-Wareth AAA, Kehraus S, Hippenstiel F, Südekum KH. Effects of thyme and oregano on growth performance of broilers from 4 to 42 days of age and on microbial counts in crop, small intestine and caecum of 42-day-old broilers. Anim Feed Sci Technol. 2012;178(3):198-202.

40. Ri CS, Jiang XR, Kim MH, Wang J, Zhang HJ, Wu SG, et al. Effects of dietary oregano powder supplementation on the growth performance, antioxidant status and meat quality of broiler chicks. Ital J Anim Sci. 2017;16(2):246-52.

41. Hashemipour H, Kermanshahi H, Golian A, Veldkamp T. Effect of thymol and carvacrol feed supplementation on performance, antioxidant enzyme activities, fatty acid composition, digestive enzyme activities, and immune response in broiler chickens. Poult Sci. 2013:92(8):2059-69.

42. Attia YA, Bakhashwain AA, Bertu NK. Thyme oil (Thyme vulgaris L.) as a natural growth promoter for broiler chickens reared under hot climate. Ital J Anim Sci. 2017;16(2):275-82.

43. Abu Hafsa SH, Ibrahim SA. Effect of dietary polyphenol-rich grape seed on growth performance, antioxidant capacity and ileal microflora in broiler chicks. J Anim Physiol Anim Nutri. 2018;102(1):268-75.

44. Yang $X$, Xin $H$, Yang $C$, Yang $X$. Impact of essential oils and organic acids on the growth performance, digestive functions and immunity of broiler chickens. Anim Nutri. 2018a;4(4):388-93.

45. Chowdhury S, Mandal GP, Patra AK. Different essential oils in diets of chickens: 1. Growth performance, nutrient utilisation, nitrogen excretion, carcass traits and chemical composition of meat. Anim Feed Sci Technol. 2018a;236:86-97.

46. Hesabi Nameghi A, Edalatian O, Bakhshalinejad R. Effects of a blend of thyme, peppermint and eucalyptus essential oils on growth performance, serum lipid and hepatic enzyme indices, immune response and ileal morphology and microflora in broilers. J Anim Physiol Anim Nutr. 2019;103(5):1388-98.

47. Liu S, Song M, Yun W, Lee J, Lee C, Kwak W, et al. Effects of oral administration of different dosages of carvacrol essential oils on intestinal barrier function in broilers. J Anim Physiol Anim Nutr. 2018b;102(5):1257-65.

48. Cengiz Ö, Köksal BH, Tatlı O, Sevim Ö, Ahsan U, Bilgili SF, et al. Effect of dietary tannic acid supplementation in corn- or barley-based diets on growth performance, intestinal viscosity, litter quality, and incidence and severity of footpad dermatitis in broiler chickens. Livest Sci. 2017;202:52-7.

49. He X, Hao D, Liu C, Zhang X, Xu D, Xu X, et al. Effect of supplemental oregano essential oils in diets on production performance and relatively intestinal parameters of laying hens. Am J Mol Biol. 2017;7:73-85.
50. Alagawany M, El-Hack MEA, Saeed M, Arain MA, Bhutto ZZ, Faslani SA, et al. Effect of some phytogenic additives as dietary supplements on performance, egg quality, serum biochemical parameters and oxidative status in laying hens. Indian J Anim Sci. 2017;87(103):100.

51. Büyükkılıç Beyzi S, Konca Y, Kaliber M, Sarı̈̈zkan S, Kocaoğlu Güçlü B, Aktuğ $E$, et al. Effects of thyme essential oil and $A, C$, and $E$ vitamin combinations to diets on performance, egg quality, MDA, and $8-\mathrm{OHdG}$ of laying hens under heat stress. J Applied Anim Res. 2020;48(1):126-32.

52. Ao X, Kim $H$. Effects of grape seed extract on performance, immunity, antioxidant capacity, and meat quality in Pekin ducks. Poult Sci. 2020;99(4): 2078-86.

53. Yang $C$, Zhang L, Cao G, Feng J, Yue M, Xu Y, et al. Effects of dietary supplementation with essential oils and organic acids on the growth performance, immune system, fecal volatile fatty acids, and microflora community in weaned piglets. J Anim Sci. 2018b;97(1):133-43.

54. Galassi G, Mason F, Rapetti L, Crovetto GM, Spanghero M. Digestibility and metabolic utilisation of diets containing chestnut tannins and their effects on growth and slaughter traits of heavy pigs. Ital J Anim Sci. 2019;18(1):746-53.

55. Luna A, Lábaque MC, Zygadlo JA, Marin RH. Effects of thymol and carvacrol feed supplementation on lipid oxidation in broiler meat. Poult Sci. 2010; 89(2):366-70.

56. Goliomytis M, Orfanou H, Petrou E, Charismiadou M, Simitzis P, Deligeorgis S. Effect of hesperidin dietary supplementation on hen performance, egg quality and yolk oxidative stability. Br Poult Sci. 2014;55(1):98-104.

57. Goliomytis M, Kartsonas N, Charismiadou MA, Symeon GK, Simitzis PE, Deligeorgis SG. The influence of naringin or hesperidin dietary supplementation on broiler meat quality and oxidative stability. PloS ONE. 2015;10(10):e0141652.

58. Kamboh AA, Zhu WY. Individual and combined effects of genistein and hesperidin supplementation on meat quality in meat-type broiler chickens. J Sci Food Agric. 2013a;93:3362-7.

59. Hernández-Coronado AC, Silva-Vázquez R, Rangel-Nava ZE, HernándezMartínez CA, Kawas-Garza JR, Hume ME, et al. Mexican oregano essential oils given in drinking water on performance, carcass traits, and meat quality of broilers. Poult Sci. 2019;98(7):3050-8.

60. Jung $\mathrm{S}$, Choe JH, Kim B, Yun H, Kruk ZA, Jo C. Effect of dietary mixture of gallic acid and linoleic acid on antioxidative potential and quality of breast meat from broilers. Meat Sci. 2010;86(2):520-6.

61. Possas A, Posada-Izquierdo GD, Pérez-Rodríguez F, Valero A, García-Gimeno $\mathrm{RM}$, Duarte MCT. Application of predictive models to assess the influence of thyme essential oil on Salmonella enteritidis behaviour during shelf life of ready-to-eat turkey products. Int J Food Microbiol. 2017;240:40-6.

62. Oh HJ, Kim IH, Song MH, Kwak WG, Yun W, Lee JH, et al. Effects of microencapsulated complex of organic acids and essential oils on growth performance, nutrient retention, blood profiles, fecal microflora, and lean meat percentage in weaning to finishing pigs. Can J Anim Sci. 2018;99(1):41-9.

63. Forte C, Ranucci D, Beghelli D, Branciari R, Acuti G, Todini L, et al. Dietary integration with oregano (Origanum vulgare L.) essential oil improves growth rate and oxidative status in outdoor-reared, but not indoor-reared, pigs. J Anim Physiol Anim Nutr. 2017;101(5):352-61.

64. Heleno SA, Martins A, Queiroz MJRP, Ferreira ICFR. Bioactivity of phenolic acids: metabolites versus parent compounds: a review. Food Chem. 2015; 173:501-13.

65. Balasundram N, Sundram K, Samman S. Phenolic compounds in plants and agri-industrial by-products: antioxidant activity, occurrence, and potential uses. Food Chem. 2006;99:191-203.

66. Bendary E, Francis RR, Ali HMG, Sarwat MI, Hady SE. Antioxidant and structure -activity relationships ( SARs ) of some phenolic and anilines compounds. Ann Agric Sci. 2013;58:173-81.

67. Wang T, Li Q, Bi K. Bioactive flavonoids in medicinal plants : structure, activity and biological fate. Asian J Pharma Sci. 2018a;13:12-23.

68. Iqbal Z, Kamran Z, Sultan J, Ali A, Ahmad S, Shahzad M, et al. Replacement effect of vitamin $E$ with grape polyphenols on antioxidant status, immune, and organs histopathological responses in broilers from 1- to 35-d age. J Applied Poult Res. 2015;24:127-34.

69. Yan Z, Zhong Y, Duan Y, Chen Q, Li F. Antioxidant mechanism of tea polyphenols and its impact on health benefits. Anim Nutr. 2020;6(2):115-23.

70. Mazur-Kuśnirek M, Antoszkiewicz Z, Lipiński K, Fijałkowska M, Purwin C, Kotlarczyk S. The effect of polyphenols and vitamin E on the antioxidant status and meat quality of broiler chickens fed diets naturally contaminated with ochratoxin A. Arc Anim Nutr. 2019;73(6):431-44. 
71. Pirgozliev V, Mansbridge SC, Rose SP, Mackenzie AM, Beccaccia A, Karadas F. I et al. Dietary essential oils improve feed efficiency and hepatic antioxidant content of broiler chickens. Animal. 2019;13(3):502-8.

72. Torki M, Sedgh-Gooya S, Mohammadi H. Effects of adding essential oils of rosemary, dill and chicory extract to diets on performance, egg quality and some blood parameters of laying hens subjected to heat stress. J Applied Anim Res. 2018;46(1):1118-26.

73. Lipiński K, Antoszkiewicz Z, Mazur-Kuśnirek M, Korniewicz D, Kotlarczyk S. The effect of polyphenols on the performance and antioxidant status of sows and piglets. Ital J Anim Sci. 2019;18(1):174-81.

74. Zhang HJ, Xian-Ren J, Mantovani G, Valdez A, Comi M, Loris A, et al. Modulation of plasma antioxidant activity in weaned piglets by plant polyphenols. Ital J Anim Sci. 2014;13:424-30.

75. Fang L, Li M, Zhao L, Han S, Li Y, Xiong B, et al. Dietary grape seed procyanidins suppressed weaning stress by improving antioxidant enzyme activity and mRNA expression in weanling piglets. J Anim Physiol Anim Nutr. 2020;104(4):1178-85.

76. Artuso-Ponte V, Pastor A, Andratsch M. Chapter 17 - The effects of plant extracts on the immune system of livestock: The isoquinoline alkaloids model. In: Florou-Paneri P, Christaki E, Giannenas I, editors. Feed Additives. London: Academic Press; 2020. p. 295-310.

77. Adaszynska-Skwirzynska M, Szczerbinska D. Use of essential oils in broiler chicken production - a review. Ann Anim Sci. 2017;17:317-35.

78. Sheoran N, Kumar R, Kumar AA, Batra K, Sihag S, Maan S, et al. Nutrigenomic evaluation of garlic (Allium sativum) and holy basil (Ocimum sanctum) leaf powder supplementation on growth performance and immune characteristics in broilers. Vet World. 2017;10:121-9.

79. Lipiński K, Mazur M, Antoszkiewicz Z, Purwin C. Polyphenols in monogastric nutrition - A review. Annals Anim Sci. 2017;17(1):41-58.

80. Rubio L, Motilva M, Romero M. Recent advances in biologically active compounds in herbs and spices: a review of the most effective antioxidant and anti-inflammatory active principles. Crit Rev Food Sci Nutri. 2013:53(9):943-53.

81. Muanda F, Kone D, Dicko A, Soulimani R, Younos C. Phytochemical composition and antioxidant capacity of three malian medicinal plant parts. J Evid Based Complement Altern Med. 2011:21-8.

82. Miguel MG. Antioxidant and anti-inflammatory activities of essential oils. Molecules. 2010;15:9252-87.

83. Soler $L$, Hermes R, Niewold TA. Macleaya cordata extract reduces inflammatory responses of intestinal epithelial cells in vivo. Am J Plant Sci. 2016;7:1531-7.

84. Alipour F, Hassanabadi A, Golian A, Nassiri-Moghaddam H. Effect of plant extracts derived from thyme on male broiler performance. Poult Sci. 2015; 94:26-30.

85. Kamboh AA, Zhu WY. Individual and combined effects of genistein and hesperidin on immunity and intestinal morphometry in lipopolysacharidechallenged broiler chickens. Poult Sci. 2014;93(9):2175-83.

86. Zhang X, Zhao L, Cao F, Ahmad H, Wang G, Wang T. Effects of feeding fermented Ginkgo biloba leaves on small intestinal morphology, absorption, and immunomodulation of early lipopolysaccharide-challenged chicks. Poult Sci. 2013;92(1):119-30.

87. Bera I, Tyagi PK, Mir NA, Begum J, Dev K, Tyagi PK, et al. Effect of dietary saponin rich soapnut (Sapindus mukorossi) shell powder on growth performance, immunity, serum biochemistry and gut health of broiler chickens. J Anim Physiol Anim Nutr. 2019;103(6):1800-9.

88. Nazarizadeh H, Mohammad Hosseini S, Pourreza J. Effect of plant extracts derived from thyme and chamomile on the growth performance, gut morphology and immune system of broilers fed aflatoxin B1 and ochratoxin A contaminated diets. Ital J Anim Sci. 2019;18(1):1073-81.

89. Liu SD, Song MH, Yun W, Lee JH, Lee CH, Kwak WG. Effects of oral administration of various essential oils on blood metabolites, intestine development, microbial enumeration and meat quality in broilers. Indian J Anim Res. 2019;53(6):762-7.

90. He S, Yu Q, He Y, Hu R, Xia S, He J. Dietary resveratrol supplementation inhibits heat stress-induced high-activated innate immunity and inflammatory response in spleen of yellow-feather broilers. Poult Sci. 2019a; 98(12):6378-87.

91. Park IJ, Cha SY, Kang M, So YS, Go HG, Mun SP, et al. Effect of proanthocyanidin-rich extract from Pinus radiata bark on immune response of specific-pathogen-free White leghorn chickens. Poult Sci. 2011;90(5):977-82.

92. Nasiroleslami M, Torki M. Including essential oils of fennel (Foeniculum vulgare) and ginger (Zingiber officinale) to diet and evaluating performance of laying hens, white blood cell count and egg quality characteristics. Adv Environ Biol. 2010:4:341-5.

93. Ghasemi R, Zarei M, Torki M. Adding medicinal herbs including garlic (Allium sativum) and thyme (Thymus vulgaris) to diet of laying hens and evaluating productive performance and egg quality characteristics. Am J Anim Vet Sci. 2010;5:151-4.

94. Harrington D, Hall H, Wilde D, Wakeman W. Chapter 11-Application of aromatic plants and their extracts in the diets of laying hens. In: FlorouPaneri P, Christaki E, Giannenas I, editors. Feed Additives. London: Academic Press; 2020. p. 187-203.

95. Mousavi A, Mahdavi AH, Riasi A, Soltani-Ghombavani M. Efficacy of essential oils combination on performance, ileal bacterial counts, intestinal histology and immunocompetence of laying hens fed alternative lipid sources. J Anim Physiol Anim Nutr. 2018;102(5):1245-56.

96. Fiesel A, Gessner DK, Most E, Eder K. Effects of dietary polyphenol-rich plant products from grape or hop on pro-inflammatory gene expression in the intestine, nutrient digestibility and faecal microbiota of weaned pigs. BMC Vet Res. 2014;10:196

97. Zhu C, Wu Y, Jiang Z, Zheng C, Wang L, Yang X, et al. Dietary soy isoflavone attenuated growth performance and intestinal barrier functions in weaned piglets challenged with lipopolysaccharide. Int Immunopharma. 2015;28(1):288-94.

98. Gessner DK, Fiesel A, Most E, Dinges J, Wen G, Ringseis R, et al. Supplementation of a grape seed and grape marc meal extract decreases activities of the oxidativestress-responsive transcription factors NF-KB andNrf2 in the duodenal mucosa of pigs. Acta Vet Scand. 2013;55:18-28.

99. Deng Q, Xu J, Yu B, He J, Zhang K, Ding X, et al. Effect of dietary tea polyphenols on growth performance and cell-mediated immune response of post-weaning piglets under oxidative stress. Arc Anim Nutr. 2010;64(1):12-21.

100. Dong L, Liu J, Zhong Z, Wang S, Wang H, Huo Y, et al. Dietary tea tree oil supplementation improves the intestinal mucosal immunity of weanling piglets. Anim Feed Sci Technol. 2019;255:114209.

101. Park SY, Bok SH, Jeon SM, Park YB, Lee SJ, Jeong TS, et al. Effect of rutin and tannic acid supplements on cholesterol metabolism in rats. Nutri Res. 2002; 22(3):283-95.

102. Abdulkarimi R, Daneshyar M, Aghazadeh A. Thyme (Thymus vulgaris) extract consumption darkens liver, lowers blood cholesterol, proportional liver and abdominal fat weights in broiler chickens. Ital J Anim Sci. 2011;10:101-5.

103. Kamboh AA, Zhu WY. Effect of increasing levels of bioflavonoids in broiler feed on plasma anti-oxidative potential, lipid metabolites, and fatty acid composition of meat. Poult Sci. 2013b;92(2):454-61.

104. Hajiaghapour M, Rezaeipour V. Comparison of two herbal essential oils, probiotic, and mannan-oligosaccharides on egg production, hatchability, serum metabolites, intestinal morphology, and microbiota activity of quail breeders. Livest Sci. 2018;210:93-8.

105. Gheisar MM, Kim IH. Phytobiotics in poultry and swine nutrition - a review. Ital J Anim Sci. 2017;17:92-9.

106. Bozkurt M, Tüzün AE. Chapter 12-Application of aromatic plants and their extracts in diets of turkeys. In: Florou-Paneri P, Christaki E, Giannenas I, editors. Feed Additives. London: Academic Press; 2020. p. 205-26.

107. Yang C, Chowdhury K, Hou Y, Gong J. Phytogenic compounds as alternatives to in-feed antibiotics: potentials and challenges in application. Pathogens. 2015:4:137-56.

108. Christaki E, Bonos E, Giannenas I, Florou-Paneri P. Aromatic plants as a source of bioactive compounds. Agriculture. 2012;2:228-43.

109. Steiner P, Syed B. Phytogenic feed additives in animal nutrition. In: Mathe A editor. Medicinal and Aromatic Plants of the World. London, UK: Springer; 2015.

110. Christaki E, Florou-Paneri P, Giannenas I, Papazahariadou M, Botsoglou NA, Spais AB. Effect of a mixture of herbal extracts on broiler chickens infected with Eimeria tenella. Anim Res. 2004:53:137-44.

111. Bozkurt M, Giannenas I, Kucukyilmaz K, Christaki E, Florou-Paneri P. An update on approaches to controlling coccidia in poultry using botanical extracts. Br Poult Sci. 2013;54:713-27.

112. Gaur S, Kuhlenschmidt TB, Kuhlenschmidt MS, Andrade JE. Effect of oregano essential oil and carvacrol on Cryptosporidium parvum infectivity in HCT-8 cells. Parasitol Int. 2018:67:170-5.

113. Qureshi S, Adil S, Abd El-Hack ME, Alagawany M, Farag MR. Beneficial uses of dandelion herb (Taraxacum officinale) in poultry nutrition. World's Poult Sci J. 2017;73:591-602.

114. Hajati H, Hassanabadi A, Golian A, Nassiri-Moghaddam H, Nassiri M, Safari R. The effect of grape seed extract and vitamin $C$ feed supplements carcass 
characteristics, gut morphology and ileal microflora in broiler chickens exposed to chronic heat stress. Iranian J Applied Anim Sci. 2015;5:155-65.

115. Yang X, Liu Y, Yan F, Yang C, Yang X. Effects of encapsulated organic acids and essential oils on intestinal barrier, microbial count, and bacterial metabolites in broiler chickens. Poult Sci. 2019;98(7):2858-65.

116. Govaris A, Botsoglou E, Florou-Paneri P, Moutas A, Papageorgiou G. Dietary supplementation of oregano essential oil and tocopheryl acetate on microbial growth and lipid oxidation of Turkey breast fillets during storage. Int J Poult Sci. 2005;4:969-75.

117. Wagle BR, Donoghue AM, Shrestha S, Upadhyaya I, Arsi K, Gupta A, et al. Carvacrol attenuates Campylobacter jejuni colonization factors and proteome critical for persistence in the chicken gut. Poult Sci. 2020;99(9): 4566-77.

118. Arsi K, Donoghue AM, Venkitanarayanan K, Kollanoor-Johny A, Fanatico AC, Blore PJ, et al. The efficacy of the natural plant extracts, thymol and carvacrol against Campylobacter colonization in broiler chickens. J Food Saf. 2014:34(4):321-5.

119. Stamilla A, Messina A, Sallemi S, Condorelli L, Antoci F, Puleio R, et al. Effects of microencapsulated blends of organics acids (OA) and essential oils (EO) as a feed additive for broiler chicken. a focus on growth performance, gut morphology and microbiology. Animals. 2020;10(3):442.

120. Zhang S, Shen YR, Wu S, Xiao YQ, He Q, Shi SR. The dietary combination of essential oils and organic acids reduces Salmonella enteritidis in challenged chicks. Poult Sci. 2019;98(12):6349-55.

121. García-Ruíz A, Bartolomé B, Martínez-Rodríguez AJ, Puello E, MartínÁlvarez PJ, Moreno-Arribas MV. Potential of phenolic compounds for controlling lactic acid bacteria growth in wine. Food Control J. 2008;19:835-41.

122. Khaksar V, Golian A, Kermanshahi H. Immune response and ileal microflora in broilers fed wheat-based diet with or without enzyme Endo feed W and supplementation of thyme essential oil or probiotic PrimaLac ${ }^{\oplus}$. Afr J Biotechnol. 2012;11:14716-23.

123. Wang $H$, Liang S, Li X, Yang X, Long F, Yang X. Effects of encapsulated essential oils and organic acids on laying performance, egg quality, intestinal morphology, barrier function, and microflora count of hens during the early laying period. Poult Sci. 2019;98(12):6751-60.

124. Bölükbasi SC, Erhan MK. Effect of dietary thyme (Thymus vulgaris) on laying hens performance and Escherichia coli (E. coli) concentration in feces. Int J Nat Eng Sci. 2007:1:55-8.

125. Bozkurt M, Bintaş E, Krrkan Ş, Akşit H, Küçükyılmaz K, Erbaş G, et al. Comparative evaluation of dietary supplementation with mannan oligosaccharide and oregano essential oil in forced molted and fully fed laying hens between 82 and 106 weeks of age. Poult Sci. 2016;95(11):2576-91.

126. Ahmed S, Hossain M, Kim G, Hwang J, Ji H, Yang C. Effects of resveratrol and essential oils on growth performance, immunity, digestibility and fecal microbial shedding in challenged piglets. Asian Australas J Anim Sci. 2013;26:683-90.

127. Diao H, Zheng P, Yu B, Mao X, Yu J, Chen D. Effects of benzoic acid and thymol on growth performance and gut characteristics of weaned piglets. Asian Australas J Anim Sci. 2015;28:827-39.

128. Verhelst R, Schroyen M, Buys N, Niewold T. Dietary polyphenols reduce diarrhea in enterotoxigenic Escherichia coli (ETEC) infected post-weaning piglets. Livest Sci. 2014;160:138-40.

129. Hosseini-Vashan SJ, Safdari-Rostamabad M, Piray AH, Sarir H. The growth performance, plasma biochemistry indices, immune system, antioxidant status, and intestinal morphology of heat-stressed broiler chickens fed grape (Vitis vinifera) pomace. Anim Feed Sci Technol. 2020;259:114343.

130. Adaszyńska-Skwirzyńska M, Szczerbińska D. The effect of lavender (Lavandula angustifolia) essential oil as a drinking water supplement on the production performance, blood biochemical parameters, and ileal microflora in broiler chickens. Poult Sci. 2019;98(1):358-65.

131. He S, Li S, Arowolo MA, Yu Q, Chen F, Hu R, et al. Effect of resveratrol on growth performance, rectal temperature and serum parameters of yellowfeather broilers under heat stress. Anim Sci J. 2019b:90(3):401-11.

132. Mohebodini H, Jazi V, Bakhshalinejad R, Shabani A, Ashayerizadeh A. Effect of dietary resveratrol supplementation on growth performance, immune response, serum biochemical indices, cecal microflora, and intestinal morphology of broiler chickens challenged with Escherichia coli. Livest Sci. 2019;229:13-21.

133. Chowdhury S, Mandal GP, Patra AK, Kumar P, Samanta I, Pradhan S, et al. Different essential oils in diets of broiler chickens: 2. Gut microbes and morphology, immune response, and some blood profile and antioxidant enzymes. Anim Feed Sci Technol. 2018b;236:39-47.
134. Aditya S, Ohh SJ, Ahammed M, Lohakare J. Supplementation of grape pomace (Vitis vinifera) in broiler diets and its effect on growth performance, apparent total tract digestibility of nutrients, blood profile, and meat quality. Anim Nutr. 2018:4(2):210-4.

135. Zhang C, Yang L, Zhao X, Chen X, Wang L, Geng Z. Effect of dietary resveratrol supplementation on meat quality, muscle antioxidative capacity and mitochondrial biogenesis of broilers. J Sci Food Agric. 2017a;98:1216-21.

136. Farahat MH, Abdallah FM, Ali HA, Hernandez-Santana A. Effect of dietary supplementation of grape seed extract on the growth performance, lipid profile, antioxidant status and immune response of broiler chickens. Animal. 2017;11(5):771-7.

137. Yang JY, Zhang HJ, Wang J, Wu SG, Yue HY, Jiang XR, et al. Effects of dietary grape proanthocyanidins on the growth performance, jejunum morphology and plasma biochemical indices of broiler chicks. Animal. 2017;11(5):762-70.

138. Chamorro S, Viveros A, Rebolé A, Rica BD, Arija I, Brenes A. Influence of dietary enzyme addition on polyphenol utilization and meat lipid oxidation of chicks fed grape pomace. Food Res Int. 2015:73:197-203.

139. Placha I, Takacova J, Ryzner M, Cobanova K, Laukova A, Strompfova V, et al. Effect of thyme essential oil and selenium on intestine integrity and antioxidant status of broilers. Br Poult Sci. 2014;55(1):105-14.

140. Hong JC, Steiner T, Aufy A, Lien TF. Effects of supplemental essential oil on growth performance, lipid metabolites and immunity, intestinal characteristics, microbiota and carcass traits in broilers. Livest Sci. 2012;144(3):253-62.

141. Tiihonen K, Kettunen H, Bento MH, Saarinen M, Lahtinen S, Ouwehand AC, et al. The effect of feeding essential oils on broiler performance and gut microbiota. Br Poult Sci. 2010;51(3):381-92.

142. Mansoori B, Nodeh H, Modirsanei M, MM K, Farkhoy M. Influence of dietary tannic acid and polyethylene glycol on growth and intestinal D-xylose absorption of broiler cockerels and activity of serum enzymes. Br Poult Sci. 2007:48:489-95.

143. Abdel-Wareth AAA, Lohakare JD. Productive performance, egg quality, nutrients digestibility, and physiological response of bovans brown hens fed various dietary inclusion levels of peppermint oil. Anim Feed Sci Technol. 2020:267:114554.

144. Yu C, Guo Y, Yang Z, Yang W, Jiang S. Effects of star anise (Illicium verum Hook.f.) essential oil on nutrient and energy utilization of laying hens. Anim Sci J. 2019;90(7):880-6.

145. Cimrin T. Thyme (Thymbra spicata L.), rosemary (Rosmarinus officinalis L.) and vitamin E supplementation of laying hens. South Af. J Anim Sci. 2019;9:912.

146. Chen Y, Chen H, Li W, Miao J, Chen N, Shao X, et al. Polyphenols in Eucalyptus leaves improved the egg and meat qualities and protected against ethanol-induced oxidative damage in laying hens. J Anim Physiol Anim Nutr. 2018;102(1):214-23.

147. Wang XC, Wang XH, Wang J, Wang H, Zhang HJ, Wu SG, et al. Dietary tea polyphenol supplementation improved egg production performance, albumen quality, and magnum morphology of Hy-Line Brown hens during the late laying period. J Anim Sci. 2018b;96(1):225-35.

148. Ding X, Yu Y, Su Z, Zhang K. Effects of essential oils on performance, egg quality, nutrient digestibility and yolk fatty acid profile in laying hens. Anim Nutr. 2017;3(2):127-31

149. Mousavi A, Mahdavi AH, Riasi A, Soltani-Ghombavani M. Synergetic effects of essential oils mixture improved egg quality traits, oxidative stability and liver health indices in laying hens fed fish oil. Anim Feed Sci Technol. 2017; 234:162-72.

150. Akbari M, Torki M, Kaviani K. Single and combined effects of peppermint and thyme essential oils on productive performance, egg quality traits, and blood parameters of laying hens reared under cold stress condition ( $6.8 \pm 3$ $\left.{ }^{\circ} \mathrm{C}\right)$. Int J Biomet. 2016;60(3):447-54.

151. Vakili R, Majidzadeh HR. Performance and egg quality of laying hens fed diets supplemented with herbal extracts and flaxseed. Poult Sci J. 2016; 2016:107-16.

152. El-Hack M, Alagawany M. Performance, egg quality, blood profile, immune function, and antioxidant enzyme activities in laying hens fed diets with thyme powder. J Anim Feed Sci. 2015;24:127-33.

153. Torki M, Akbari M, Kaviani K. Single and combined effects of zinc and cinnamon essential oil in diet on productive performance, egg quality traits, and blood parameters of laying hens reared under cold stress condition. Int Biomet. 2015:59(9):1169-77.

154. Gharaghani H, Shariatmadari F, Torshizi M. Effect of fennel (Foeniculum vulgare Mill.) used as a feed additive on the egg quality of laying hens under heat stress. Braz J Poult Sci. 2015;17:199-207. 
155. Jahanian E, Jahanian R, Rahmani HR, Alikhani M. Dietary supplementation of Echinacea purpurea powder improved performance, serum lipid profile, and yolk oxidative stability in laying hens. J Appl Anim Res. 2015;45:45-51.

156. Abdel-Wareth AAA, Lohakare JD. Effect of dietary supplementation of peppermint on performance, egg quality, and serum metabolic profile of Hy-Line Brown hens during the late laying period. Anim Feed Sci Technol. 2014;197:114-20

157. Özek K, Wellmann KT, Ertekin B, Tarım B. Effects of dietary herbal essential oil mixture and organic acid preparation on laying traits, gastrointestinal tract characteristics, blood parameters and immune response of laying hens in a hot summer season. J Anim Feed Sci. 2011;20(4):575-86.

158. Sahin K, Akdemir F, Orhan C, Tuzcu M, Hayirli A, Sahin N. Effects of dietary resveratrol supplementation on egg production and antioxidant status. Poult Sci. 2010;89(6):1190-8.

159. Nazar FN, Videla EA, Marin RH. Thymol supplementation effects on adrenocortical, immune and biochemical variables recovery in Japanese quail after exposure to chronic heat stress. Animal. 2019;13(2):318-25.

160. Mehri M, Sabaghi V, Bagherzadeh-Kasmani F. Mentha piperita (peppermint) in growing Japanese quails diet: Performance, carcass attributes, morphology and microbial populations of intestine. Anim Feed Sci Technol. 2015;207:104-11.

161. Guo L, Hua J, Luan Z, Xue P, Zhou S, Wang X, et al. Effects of the stems and leaves of Astragalus membranaceus on growth performance, immunological parameters, antioxidant status, and intestinal bacteria of quail. Anim Sci J. 2019;90(6):747-56

162. Fernandez ME, Kembro JM, Ballesteros ML, Caliva JM, Marin RH, Labaque MC. Dynamics of thymol dietary supplementation in quail (Coturnix japonica): Linking bioavailability, effects on egg yolk total fatty acids and performance traits. PloS ON. 2019;4(5):e0216623.

163. Abouelezz K, Abou-Hadied M, Yuan J, Elokil AA, Wang G, Wang S, et al. Nutritional impacts of dietary oregano and Enviva essential oils on the performance, gut microbiota and blood biochemicals of growing ducks. Animal. 2019;13(10):2216-22.

164. Ding X, Wu X, Zhang K, Bai S, Wang J, Peng H, et al. Dietary supplement of essential oil from oregano affects growth performance, nutrient utilization, intestinal morphology and antioxidant ability in Pekin ducks. J Anim Physiol Anim Nutr. 2020:104(4):1067-74.

165. Giannenas I, Papaneophytou CP, Tsalie E, Pappas I, Triantafillou E, Tontis D, et al. Dietary supplementation of benzoic acid and essential oil compounds affects buffering capacity of the feeds, performance of turkey poults and their antioxidant status, $\mathrm{pH}$ in the digestive tract, intestinal microbiota and morphology. Asian Australas J Anim Sci. 2014;27(2):225-36

166. Koncicki A, Śmiałek M, Tykałowski B, Pestka D, Stenzel T. The influence of phytoncides on the immune system of broiler chickens and turkeys. Cent Eur J Immunol. 2015;40(3):287-91.

167. Mikulski D, Zdunczyk Z, Jankowski J, Juśkiewicz J. Effects of organic acids or natural plant extracts added to diets for turkeys on growth performance, gastrointestinal tract metabolism and carcass characteristics. J Anim Feed Sci. 2008;17:233-46.

168. Li QH, Yan HS, Li HQ, Gao JJ, Hao RR. Effects of dietary supplementation with grape seed procyanidins on nutrient utilisation and gut function in weaned piglets. Animal. 2020;14(3):491-8.

169. Wang $R$, Yu H, Fang $H$, Jin $Y$, Zhao $Y$, Shen J, et al. Effects of dietary grape pomace on the intestinal microbiota and growth performance of weaned piglets. Arc Anim Nutr. 2020a;74(4):296-308.

170. Kafantaris I, Stagos D, Kotsampasi B, Hatzis A, Kypriotakis A, Gerasopoulos K, et al. Grape pomace improves performance, antioxidant status, fecal microbiota and meat quality of piglets. Animal. 2018;12(2):246-55.

171. Fang J, Cao Y, Matsuzaki M, Suzuki H, Kimura H. Effects of apple pomacemixed silage on growth performance and meat quality in finishing pigs. Anim Sci J. 2016:87(12):1516-21.

172. Hao R, Li Q, Zhao J, Li H, Wang W, Gao J. Effects of grape seed procyanidins on growth performance, immune function and antioxidant capacity in weaned piglets. Livest Sci. 2015;178:237-42.

173. Wang $M$, Huang $H, H u Y$, Huang J, Yang H, Wang L, Chen S, et al. Effects of dietary microencapsulated tannic acid supplementation on the growth performance, intestinal morphology, and intestinal microbiota in weaning piglets. J Anim Sci. 2020b;98(5):1-12.

174. Biagi G, Cipollini I, Paulicks BR, Roth FX. Effect of tannins on growth performance and intestinal ecosystem in weaned piglets. Arch Anim Nutri. 2010;64:121-35.

175. Bilić-Šobot D, Kubale V, Škrlep M, Čandek-Potokar M, Prevolnik Povše M, Fazarinc $\mathrm{G}$, et al. Effect of hydrolysable tannins on intestinal morphology, proliferation and apoptosis in entire male pigs. Arc. Anim Nutri. 2016;70(5): 378-88.

176. Bee G, Silacci P, Ampuero-Kragten S, Čandek-Potokar M, Wealleans AL, Litten-Brown J, et al. Hydrolysable tannin-based diet rich in gallotannins has a minimal impact on pig performance but significantly reduces salivary and bulbourethral gland size. Animal. 2017;11(9):1617-25.

177. Bertol T, Ludke JV, Campos R, Kawski V, Jr A, Figueiredo E. Inclusion of grape pomace in the diet of pigs on pork quality and oxidative stability of omega3 enriched fat. Ciência Rural. 2017:47.

178. Lee SH, Shinde PL, Choi JY, Kwon IK, Lee JK, Pak SI, et al. Effects of tannic acid supplementation on growth performance, blood hematology, iron status and faecal microflora in weanling pigs. Livest Sci. 2010;131(2):281-6.

179. Zeng Z, Xu X, Zhang Q, Li P, Zhao P, Li Q, et al. Effects of essential oil supplementation of a low-energy diet on performance, intestinal morphology and microflora, immune properties and antioxidant activities in weaned pigs. Anim Sci J. 2015;86(3):279-85.

180. Li SY, Ru YJ, Liu M, Xu B, Péron A, Shi XG. The effect of essential oils on performance, immunity and gut microbial population in weaner pigs. Livest Sci. 2012;145(1):119-23.

181. Xu YT, Liu L, Long SF, Pan L, Piao XS. Effect of organic acids and essential oils on performance, intestinal health and digestive enzyme activities of weaned pigs. Anim Feed Scie Technol. 2018;235:110-9.

182. Su G, Zhou X, Wang Y, Chen D, Chen G, Li Y, et al. Dietary supplementation of plant essential oil improves growth performance, intestinal morphology and health in weaned pigs. J Anim Physiol Anim Nutr. 2020;104(2):579-89.

\section{Ready to submit your research? Choose BMC and benefit from:}

- fast, convenient online submission

- thorough peer review by experienced researchers in your field

- rapid publication on acceptance

- support for research data, including large and complex data types

- gold Open Access which fosters wider collaboration and increased citations

- maximum visibility for your research: over $100 \mathrm{M}$ website views per year

At $\mathrm{BMC}$, research is always in progress.

Learn more biomedcentral.com/submissions 